\title{
3 \\ Police Legitimacy and the Authority of the State
}

\author{
ANTHONY E BOTTOMS AND JUSTICE TANKEBE
}

Leslie Green begins his book on the authority of the state with the following observations:

All modern states claim authority over their citizens, and that is one thing which distinguishes them from bands of robbers. ... [T] he state's authority ... also claims to be supreme ... It claims to regulate [people's] most vital interests, and to do so with supremacy over all other mechanisms of social control. Sometimes these grandiose claims are hollow. In a society undergoing upheaval they cannot be made effective and quickly become legal fictions. Even when they are effective they may be unjustified, for legitimacy is not among the existence conditions for a state. However-and here is the real importance of Weber's celebrated argument-a belief in its legitimacy tends to increase its stability and effectiveness. It is therefore a crucial question in what circumstances, if any, such beliefs are justified. ${ }^{1}$

In this paragraph may be found three key propositions, each of which is of importance for this chapter. They are as follows.

First, Green claims that all modern states claim authority, and that this makes them different from 'bands of robbers' or (let us say to simplify matters) from hostage takers. Hostage takers have power over their captives, but that power is exercised only by force or threat of force; they do not claim more than this. The point of the comparison that Green makes is, precisely, that modern states do claim something more than this naked power; they claim (note the normative language) the right to rule. Accordingly, in the famous distinction drawn by Herbert Hart between the state and a gunman, those held in thrall by a gunman/hostage taker feel obliged to obey him, whereas the state's claim to exercise authority, if substantiated, results in citizens feeling a sense of obligation to obey those in power. ${ }^{2}$

\footnotetext{
1 L Green, The Authority of the State (Oxford, Clarendon Press, 1990) 1.

2 HLA Hart, The Concept of Law 3rd edn edited by L Green (Oxford, Oxford University Press, 2012) 82ff.
} 
Second, Green claims that even a state that has claimed authority over its citizens, and is maintaining effective government, is not necessarily legitimate, because effectiveness does not in itself guarantee legitimacy. Rather, the state will only be legitimate if its claim to authority is justified. This raises, of course, the question of what is meant by 'justification' in this context; and that is a point to which we must return.

Third, Green draws attention to Max Weber's argument that if citizens believe that a state is legitimate, this will increase the state's 'stability and effectiveness'. ${ }^{3}$ Green endorses Weber's view, but Weber's argument has subsequently been criticised as inadequate by David Beetham, ${ }^{4}$ in a discussion in which the concept of justification plays a pivotal role. This point will also require further consideration.

We shall pursue some of these theoretical issues about legitimacy and justification before turning, in the second section of this chapter, to our main empirical focus, namely the public police. The third and fourth sections then examine aspects of police legitimacy through the lenses provided by the theorisation of Bernard Williams (the 'Basic Legitimation Demand') ${ }^{5}$ and Amartya Sen (the 'impartial spectator'). ${ }^{6}$ In the final section, we turn to a consideration of how the police might best respond to the public's 'Basic Legitimation Demand'.

\section{LEGITIMACY AND JUSTIFICATION}

To develop some of the issues raised in the introduction, two questions are tackled in this section. First, is the justification provided by legitimacy empirical or normative? Second, if legitimacy is (or to the extent that it is) empirical, is the test of legitimacy adequately captured by Weber's claim about 'beliefs in legitimacy'?

\section{A. Empirical or Normative Justification?}

As regards the first question, the definitions provided by Wilfried Hinsch have been influential. According to Hinsch, in empirical conceptions of legitimacy, 'a norm or an institutional arrangement is legitimate if, as a matter of fact, it finds the approval of those who are supposed to live in

\footnotetext{
${ }^{3} \mathrm{M}$ Weber, Economy and Society: An Outline of Interpretive Sociology 2 Vols, edited by G Roth and C Wittich (Berkeley, University of California Press, 1978).

4 D Beetham, The Legitimation of Power (London, Macmillan, 1991).

5 B Williams, In the Beginning was the Deed: Realism and Moralism in Political Argument, edited by G Hawthorn (Princeton NJ, Princeton University Press, 2005).

6 A Sen, The Idea of Justice (London, Allen Lane, 2009).
} 
this group' ${ }^{7}$ By contrast, in the normative conception, a norm or an institutional arrangement is legitimate if it meets 'objective [normative] criteria of legitimacy'. ${ }^{8}$ Which of these conceptions is to be preferred?

The empirical justification is vulnerable to some obvious criticisms. Suppose that those in power in a given state ('Dystopia') propose, in Hinsch's language, an 'institutional arrangement' whereby members of an unpopular ethnic minority group (comprising only 0.01 per cent of the whole population) will all be compulsorily deported, against their will, to a barren uninhabited island owned by Dystopia, simply because the minority group is disliked. Suppose also that this proposed policy is overwhelmingly approved in a referendum. On the empirical conception of legitimacy, the policy must be considered legitimate, since it has secured, in Hinsch's just-quoted formulation, 'the approval of those who are supposed to live in this group'. On the other hand, the policy is clearly wrong, and indeed offensive, to anyone who takes the concept of equal human rights seriously. Accordingly, on what Hinsch in the quotation above calls 'objective [normative] criteria of legitimacy' it is illegitimate because it is morally unjustifiable.

This line of thought provides a very real objection to an exclusively empirical conception of legitimacy. However, the objection should not lead us too quickly to dismiss the relevance of empirical issues when analysing the legitimacy of state power. To see why this is so, it will be helpful to turn to Bernard Williams' analysis of legitimacy.

According to Williams, 'the first political question' for any society is essentially Hobbesian; it concerns how that society can establish and maintain 'order, protection, safety, trust, and the conditions of cooperation'.9 Williams considers this to be the first question because an adequate response to it is a necessary 'condition for solving, indeed, posing others' ${ }^{10}$ That is to say, if there is no order, safety, trust or co-operation in a given society (or a part of that society), it will not be possible properly to consider issues such as the promotion of the health and education of members of its population. Moreover, this first question is, in Williams' view, a perennial question; in specific situations, threats to 'order, safety, trust' and so on can and do arise, often unexpectedly. Thus, in any given society there is no once and for all solution to the first question; it needs to be solved 'all the time'. ${ }^{11}$

These thoughts can be developed by reference to Dennis Wrong's analysis of social order, in which he postulates that social order always requires both

\footnotetext{
7 W Hinsch, 'Justice, Legitimacy, and Constitutional Rights' (2010) 13 Critical Review of International Social and Political Philosophy 39 at 40.

8 Ibid at 41.

9 Williams, above $\mathrm{n} 5$ at 3.

10 Ibid.

11 Ibid.
} 
regularity and rule. ${ }^{12}$ When someone speaks of order (not specifically social order), she or he 'means regularity, predictability and system as opposed to randomness, chance and chaos'; accordingly, in the social world, order requires the development of 'regular and recurrent patterns of [social] interaction'. ${ }^{13}$ Such patterns in turn generate a significant level of predictability in social life, and thus of stable expectations among citizens. Stable expectations are very important both for the establishment of trust and for the wellbeing of individuals; the social-scientific evidence is clear that a degree of regularity or routine (leading to expectations of 'how things will be tomorrow') is vital to what Anthony Giddens has termed humans' sense of 'ontological security'. ${ }^{14}$

To create this sense of stability in groups of any size, it is necessary that certain people should have greater power than others to shape how the group or society will function. This is what Wrong refers to as rule. ${ }^{15}$ Williams is blunt in his analysis of one basic feature of 'rule'; it means, he says, that 'one lot of people' has power over 'another lot of people'. ${ }^{16}$ Since 'might does not imply right' (or, more technically, 'power itself does not justify'), this in turn entails that some justification for holding power needs to be provided. If power is not justified, then the result will be, according to Williams, terror, not a truly political solution; moreover, the power-holders will become part of the problem, instead of the solution to the problem. To avoid power-holders becoming part of the problem, they accordingly need to develop narratives of legitimation: 'something has to be said to explain (to the less empowered, to concerned bystanders, to children being educated in this structure, etc) what the difference is between the solution and the problem' ${ }^{17}$

As will be clear from the preceding paragraph, Williams places himself firmly within what is sometimes called the 'realist' camp of political philosophy; indeed, he argues for 'concepts and explanations which are rooted in our more local practices, our culture, and our history', ${ }^{18}$ and therefore 'ring true in the historical context in which they are made'. ${ }^{19} \mathrm{He}$ contrasts

12 D Wrong, The Problem of Order: What Unites and Divides Society (Cambridge MA, Harvard University Press, 1994) ch 3.

13 Ibid at 37,5 .

14 A Giddens, The Constitution of Society (Cambridge, Polity Press, 1984) 50-64.

15 In the memorable language of the American jurist Karl Llewellyn, the question of 'rule' involves asking who has 'The Say' in a given society, where 'The Say' is defined as 'the allocation of authority and the arrangement of procedures which legitimize action as being authoritative': K Llewellyn, 'The Normative, the Legal and the Law-Jobs: The Problem of Juristic Method' (1940) 49 Yale Law Journal 1355 at 1373 and 1383-87.

16 Williams, above $\mathrm{n} 5$ at 5 .

17 Ibid.

18 B Williams, Philosophy as a Humanistic Discipline, edited by AW Moore (Oxford, Oxford University Press, 2006) 186-87.

19 E Hall, 'Bernard Williams and the Basic Legitimation Demand: A Defence' (2015) 63 Political Studies 466 at 468. Hall's article contains a useful summary of, and responses 
realism with what he calls 'political moralism', defined as 'views that make the moral prior to the political'. ${ }^{20}$ Williams argues that among the deficiencies of political moralism is a 'universalistic tendency which encourages it to inform past societies about their failings', although such judgements are 'useless'. ${ }^{21}$ By contrast, the notion of political legitimacy can sensibly be applied to past societies, taking into account the socio-political character of those societies:

It is a human universal that some people coerce or try to coerce others, and nearly a universal that some people live under an order in which some of the coercion is intelligible and acceptable. [It can therefore] be an illuminating question ... to ask how far, and in what respects, a given society of the past is an example of the human capacity for intelligible order, or of the human tendency to unmediated coercion. $^{22}$

In contemporary societies, the judgement of legitimacy must be equally contextual.

What we acknowledge as legitimate, here and now, is what, here and now, makes sense as a legitimation of power as authority; and discussions about whether it does make sense will be engaged, first-order discussions using our moral, social, interpretive and other concepts. ${ }^{23}$

It will be noted that 'moral concepts' are included within this process; this emphasises that Williams' rejection of political moralism is a rejection only of the priority of the moral in political discussion, and 'does not deny that there can be local applications of moral ideas in politics'. ${ }^{24}$

Taking Williams' analysis together with the identified weakness of the purely empirical version of legitimacy (see above), it is possible to advocate the adoption of a primarily empirical approach to legitimacy that will nevertheless work on a bedrock of inalienable normative (or moral) commitments. A model of this kind will allow us to avoid describing as 'legitimate' situations (such as the imagined proposal in Dystopia, above) where the majority empirical view is morally abhorrent. We shall develop this point later in the chapter.

to, various criticisms of Williams' approach that have appeared in the political science literature.

20 Williams, above n 5 at 2. According to Williams, political moralism includes both utilitarianism and Kantianism, and therefore also much recent political philosophy, including that of John Rawls in his classic A Theory of Justice (Oxford, Oxford University Press, 1972) and Political Liberalism (New York, Columbia University Press, 1993).

21 Williams, above n 5 at 10.

22 Ibid.

23 Ibid at 11. In this quotation, we have spelled out in full Williams' abbreviations of 'LEG' (legitimacy) and 'MS' (make sense).

24 Ibid at 8 . 


\section{B. 'Belief in Legitimacy' or 'Justified by Moral Beliefs'?}

In the early 1990s, the political sociologist David Beetham developed what has now become a classic conceptualisation of legitimacy. ${ }^{25}$ As a sociologist, Beetham insists that legitimacy must be understood 'in given social contexts rather than independent of any particular context'. ${ }^{26}$ However, he is critical of Max Weber's view that when, sociologically, one observes a 'reliable basis for a given domination', this is normally supported by a 'belief in [the] legitimacy' of the domination. ${ }^{27}$ Beetham has two principal objections to Weber's view. First, he claims that by emphasising beliefs, Weber has ignored certain elements of legitimacy that 'are not really to do with beliefs at all', such as actions that confer legitimacy (ie contribute to making power legitimate), regardless of the beliefs of the actor; Beetham gives the examples of swearing an oath of allegiance, or voting in an election. ${ }^{28}$ This aspect of legitimacy can sometimes cause real dilemmas for those who oppose a given political regime: for example, within an authoritarian state, if a civil rights organisation decides to try to challenge a particular law, it knows that the very act of using the courts of the state could be read as conferring legitimacy upon it.

Second, Beetham argues that Weber 'misrepresents the relationship between beliefs and legitimacy'. That is because, according to Beetham, 'a given power relationship is not legitimate because people believe in its legitimacy, but because it can be justified in terms of their beliefs'. ${ }^{29} \mathrm{He}$ agrees that this 'may seem a fine distinction', but he regards it as fundamental because only the latter formulation properly captures the fact that legitimacy, as seen by citizens, is 'an assessment of the degree of congruence, or lack of it, between a given system of power and the beliefs, values and expectations that provide its justification'. ${ }^{30}$ These are subtle points, which are perhaps better understood when we realise that the two authors are writing from different standpoints. As we shall show more fully later, Weber's main concern is whether a given power-holder can secure obedience from his/her subjects; and from that point of view, as Leslie Green put it in his comment on Weber quoted at the beginning of this chapter, it is true that 'belief in [the state's] legitimacy tends to increase its stability and effectiveness'. ${ }^{31}$ However, within such a framework, there might be little interest in exploring the content of the beliefs in question. By contrast, Beetham

25 Beetham, above n 4. See also D Beetham, 'Revisiting Legitimacy, Twenty Years On', in $\mathrm{J}$ Tankebe and A Liebling (eds), Legitimacy and Criminal Justice: An International Exploration (Oxford, Oxford University Press, 2013).

26 Beetham, above $\mathrm{n} 4$ at 6.

27 Weber, above $\mathrm{n} 3$ at 213.

28 Beetham, above $\mathrm{n} 4$ at 12 .

29 Ibid at 11.

${ }^{30}$ Ibid (emphasis added).

31 Green, above $\mathrm{n} 1$ at 1 . 
is more substantively concerned with the 'beliefs, values and expectations' of the subjects of a given state, and how these relate to the justification of authority offered by power-holders. A main virtue of his approach is therefore that it focuses research attention on the justifications offered by powerholders, and how these justifications are responded to by citizens; hence, it can address more directly the question 'why people acknowledge the legitimacy of power at one time or place and not another'. ${ }^{32}$ As we shall argue more fully later in this chapter, to understand such matters will normally require close attention to the history and cultural context of a given society.

Within this theoretical framework, Beetham goes on to propose that there are three components of legitimacy that are universal in form, but which vary in their specific content in different societies. These are, first, the legality of the actions of power-holders; second, the justifiability of the actions of power-holders in terms of the shared values within that society; and third, expressions of consent by citizens (that is, actions conferring legitimacy). ${ }^{33}$ This threefold conceptualisation has proved very influential in criminal justice-related discussions of legitimacy.

\section{POLICING AND THE ENFORCEMENT OF STATE AUTHORITY}

Max Weber famously defined the state as a ruling political organisation that, within a given territorial area, 'successfully upholds the claim to the monopoly of the legitimate use of physical force in the enforcement of its order'. ${ }^{34}$ Others have claimed that the state arose historically as a solution to 'the problem of order' (which is Bernard Williams' 'first question'see above).

Both of these claims have considerable relevance for contemporary police services. In modern societies, the public police are the principal non-military group authorised to use force, and they also play a fundamental role in helping to resolve Williams' 'first question' (which, it will be recalled, is also a perennial question). For example, if a situation of violent disorder develops in a city centre, it is the police who will be called upon to deal with it, using force if necessary. This is why it has been claimed that the police are 'the state made flesh ... [T] hey are the most direct representatives of the state for citizens given their visible, uniformed, 24-hour presence on the streets and their crucial involvement in social intervention and law enforcement'. ${ }^{35}$ It

32 Beetham, above $\mathrm{n} 4$ at 10.

33 Ibid at 20

34 Weber, above $\mathrm{n} 3$ at 54; see also N MacCormick, Institutions of Law (Oxford, Oxford University Press, 2007) 39-40.

35 M Punch, 'Police Corruption and Its Prevention' (2000) 8 European Journal of Criminal Policy and Research 301 at 322. There is a known danger in overstating claims of this kind. This danger has been described by Newburn and Reiner as 'police fetishism', founded on 'the 


\section{Anthony E Bottoms and Justice Tankebe}

follows that the role of the public police must be an important topic in any serious discussion of the authority of the state.

We need to note, however, that the police, while themselves part of the state, can be and often are held to account by other elected or appointed bodies (for example, a parliamentary committee, or a national or regional government). This can, importantly, include being held accountable for their failure to provide, for a particular group, an adequate solution to Williams' 'first question', namely the establishment of conditions of 'protection, safety [and] trust'. ${ }^{36}$ An example of such a failure, and subsequent calling to account, can be seen in the report of an independent inquiry into widespread child sex abuse in Rotherham, England. The Inquiry Report, in its Executive Summary, commented that 'it is hard to describe the appalling nature of the abuse that child victims suffered'; these sufferings included some victims being 'raped by multiple perpetrators, trafficked to other towns and cities ... [and being] abducted, beaten and intimidated'. ${ }^{37}$ The police for the area were among those strongly criticised for a very inadequate official response:

At an operational level, the Police gave no priority to [child sexual abuse], regarding many child victims with contempt and failing to act on their abuse as a crime ... [S]tark evidence came in 2002, 2003 and 2006 with three reports known to the Police and the Council which could not have been clearer in their description of the situation in Rotherham. The first of these reports was effectively suppressed ... The other two reports ... were ignored and no action was taken to deal with the issues that were identified in them. ${ }^{38}$

The importance of policing in relation to issues of public order and public protection is both physical and symbolic. One traditional way of assessing the relevance of the police's physical presence has been by researching the relationship between crime rates and the numbers of police working in an area. However, a high-profile academic review body in the United States (the Committee to Review Research on Police Policy and Practices) concluded that, despite some evidence from econometric studies that supported the existence of such a relationship, in general it is 'difficult to draw strong

ideological assumption that the police are a functional prerequisite of social order, the thin blue line defending against chaos'. The case against such fetishism, these authors argue, is that many societies have existed without a formal police service, and that many contemporary societies are experiencing a 'pluralization of policing', with a multiplicity of actors involved in the provision of aspects of security and protection: T Newburn and R Reiner, 'Policing and the Police' in M Maguire, R Morgan and R Reiner (eds), Oxford Handbook of Criminology 4th edn (Oxford, Oxford University Press, 2007) at 912. We do not deny that 'police fetishism' exists, but Punch's quotation does not exemplify it; the public police are indeed, in contemporary states, the principal non-military institutional guarantors of social order, and therefore, as Punch claimed, in a real sense 'the state made flesh'.

36 Williams, above $\mathrm{n} 5$ at 3.

37 A Jay, Independent Report into Child Sexual Abuse in Rotherham, 1997-2013 (Rotherham, Rotherham Metropolitan Borough Council, 2014) 1.

38 Ibid. 
policy conclusions' from this type of research, given the number of potentially confounding variables in play. ${ }^{39}$ Of course, also, mere numbers are a crude criterion, because much depends on what the employed police are doing with their time. Thus, the real evidence for the effectiveness of police activity lies elsewhere: the same US committee concluded that where the police applied a diverse array of approaches (not simply law enforcement) in a focused way, the research showed moderate to strong evidence of effectiveness in crime reduction. ${ }^{40}$

Turning to the symbolic effects of policing within social order, a leading British police scholar, Martin Innes, has pointed out that in much of the criminological literature on the effects of police actions, 'the extent to which [the intervention] ... depends upon and pivots around communication has been neglected'. ${ }^{41}$ As an illustration of this point, he describes events in two areas where homicides had recently been committed, and the local police had followed the standard operating procedure in such circumstances, namely to increase the levels of uniformed patrols. There were contrasting citizen reactions (respectively positive and negative) in the two areas, and the explanation of the difference was straightforward. In the first site, the police had 'explained to local residents what was happening, and why they would see more police patrolling'. By contrast, in the second area there was no explicit communication with residents, and they reached the conclusion that with all these police about 'there must be something [bad] going on'-a perception that created anxiety precisely because it seemed to be a signal that the regular normative order was under threat. ${ }^{42}$ Thus, the same policy had unintentionally generated different normative messages in the two areas, with contrasting outcomes; and the contrast well illustrates the important symbolic effect that the actions of a police service can have on social order and social confidence. ${ }^{43}$

In liberal democracies, members of the public know that an important function of public police is to protect them; and even in residential areas with active criminal subcultures, citizens' preference is often for more rather

39 WG Skogan and K Fryall (eds), Fairness and Effectiveness in Policing: The Evidence (Washington DC, National Academies Press, 2004) 225.

40 Ibid ch 6, especially Fig 6.1. Of the more focused strategies, 'problem-oriented policing' was found to be moderately effective, and 'problem solving in crime hot spots' strongly effective. On the latter, see also AA Braga and DL Weisburd, Policing Problem Places: Crime Hot Spots and Effective Prevention (New York, Oxford University Press, 2010).

41 M Innes, Signal Crimes: Social Reactions to Crime, Disorder and Control (Oxford, Oxford University Press, 2014) 129.

42 Ibid at 135.

43 Innes describes an act of symbolic communication that helps to sustain social order as a 'control signal'. For an argument, supported by small-scale empirical research, that there are important links between civil renewal, control signals and neighbourhood safety, see AE Bottoms and A Wilson, 'Civil Renewal, Control Signals and Neighbourhood Safety', in T Brannan, P John and G Stoker (eds), Re-Energizing Citizenship: Strategies for Civil Renewal (Basingstoke, Palgrave Macmillan, 2007). 


\section{Anthony E Bottoms and Justice Tankebe}

than less police presence. ${ }^{44}$ Yet in order to protect, the police must on occasion act coercively against certain individuals, and in some circumstances this can raise genuine questions about their legitimacy. Take, for example, the police practice of stopping and searching individuals suspected of possible involvement in crime. It has been said that 'no form of direct government control comes close to these stops in sheer numbers, frequency, proportion of the population affected, and, in many instances, the degree of coercive intrusion'. ${ }^{45}$ Research shows that if such stops are conducted in very large numbers, and/or disproportionately against a particular minority group, and/or in a very aggressive manner, then issues about the legitimacy of the police are raised. ${ }^{46}$ Such practices, carried out by a front-line state authority, therefore communicate 'powerful messages', positive or negative, concerning whether the state truly values the 'citizenship and equality' of those who live under its protection. ${ }^{47}$

In the context of strategic thinking about policing, at least in Britain, issues of this kind have led to the widespread use by police leaders of the phrase 'policing by consent'. Although this phrase has its difficulties (see later discussion), it is intended to capture the correct insight that the police can, in the last resort, only retain full authority and effectiveness with the consent of the general population. That is to say, they claim the right to exercise state power, but that claim requires the consent of those whom they police if it is not to appear, in Leslie Green's apt word, 'hollow'48 (see the introduction to this chapter).

\section{III. 'POLICING BY CONSENT' AND THE BASIC LEGITIMATION DEMAND}

We can usefully pursue the important question of 'policing by consent' by returning to the theorisation of Bernard Williams. In his view, as in that of Leslie Green, a state is only legitimate if the claimed authority of the power-holders has been justified. For Williams, what distinguishes a legitimate from an illegitimate state is that the former meets what he calls the

44 For example, in a high-crime public housing development in Sheffield, where there was an active although not organised criminal subculture in one part of the area, over 60 per cent of survey respondents thought there were not enough police patrols in the area, and only 3 per cent thought there were too many: AE Bottoms, RI Mawby and P Xanthos, 'A Tale of Two Estates' in D Downes (ed), Crime and the City: Essays in Memory of John Barron Mays (Basingstoke, Macmillan, 1989) Table 6.

45 CR Epp, S Maynard-Moody and DP Haider-Markel, Pulled Over: How Police Stops Define Race and Citizenship (Chicago, University of Chicago Press, 2014) 2.

46 For a famous British example of this, see the report by a senior judge into the 1981 riots in Brixton, London: Lord Scarman, The Brixton Disorders 10-12 April 1981, Cmnd 8427 (London, Her Majesty's Stationery Office, 1981).

47 Epp et al, above n 45 at 2.

48 Green, above $\mathrm{n} 1$ at 1. 
'Basic Legitimation Demand'. ${ }^{49}$ This concept connects directly to his earlier analysis of 'the first political question' (see above), as Geoffrey Hawthorn explains:

The first question is always with us, and fundamental to all politics. In principle, and, if there are no scruples, in practice also, putting a stop to disorder is not difficult. It requires the effective use of state power. But if there are no scruples, the solution will become the problem. Those subject to state power will lose their freedom, and worse. They will ask what the nature of state's protection and its price are to be, and they will want a reasonable reply. They will make what Williams calls a 'Basic Legitimation Demand'. ${ }^{50}$

The terminology is significant here. As we have commented elsewhere, there is a distinction between legitimation, which occurs when 'a ruler seeks to make, enhance or cultivate his/her claim to have the right to rule' and legitimacy, which is 'an attribution conferred on a power-holder by his or her audience(s), acknowledging that he/she [has] ... the right to rule'. ${ }^{51}$ The basic legitimation demand is therefore a demand by subjects that the powerholder should provide adequate justification of his/her claim to rule.

We should note also that, as Williams describes it, the basic legitimation demand is a normative demand by subjects, but he insists that this does not make it a version of 'political morality'. Political morality claims the priority of the moral over the political, but the basic legitimation demand does not; rather, it 'comes from a conception of what could count as answering a demand for justification of coercive power'. Such a demand is 'implicit in the very idea of a legitimate state, and so is inherent in any politics'. ${ }^{52}$

\section{A. A Legitimation for Every Citizen?}

Williams develops his argument about the basic legitimation demand in the following way. Suppose that

A coerces B and claims that B would be wrong to fight back ... By doing this, A claims that his actions transcend the conditions of warfare, and this gives rise to a demand [by B] for justification of what A does. When A is the state, these claims constitute its claim of authority over B. So we have a sense in which the [basic legitimation demand] itself requires a legitimation to be given to every subject. $^{53}$

49 Williams, above n 5 at 4.

50 G Hawthorn, 'Introduction' in Williams, above n 5 at xii. This collection of essays by Williams was published posthumously, with Hawthorn as the editor of the volume.

51 AE Bottoms and J Tankebe, 'A Voice Within: Power-Holders' Perspectives on Authority and Legitimacy' in Tankebe and Liebling, above n 25 at 64.

52 Williams, above n 5 at 8.

53 Ibid at 6 . 
As noted above, Williams also claims that what political subjects 'acknowledge as legitimate' is what 'makes sense [to them] as a legitimation of power as authority'. ${ }^{54}$ These are very interesting arguments, which we need to examine with some care.

What Williams is addressing in the first part of the above quotation is the question of political authority - an issue which, as Margaret Gilbert has noted, has received far less attention from political philosophers than has that of political obligation. ${ }^{55}$ But authority is not a trivial question, and indeed for front-line police officers their authority is something that can be (and is) regularly put to the test on their working shifts. ${ }^{56}$

Margaret Gilbert's suggested account of political authority, or the 'basic case of one person's standing to issue commands, as opposed to mere imperatives, to another' is as follows:

$\mathrm{X}$ has the standing to command $\mathrm{Y}$, subject to conditions $\mathrm{C}$, if and only if $\mathrm{X}$ and $\mathrm{Y}$ are subject to a joint commitment such that, in order to conform to it, $\mathrm{Y}$ must do what $\mathrm{X}$ says, subject to conditions C. For in that case $\mathrm{Y}$ owes it to $\mathrm{X}$ to do what $\mathrm{X}$ says, and it is not clear that there is any other way of bringing that situation about. ${ }^{57}$

Within this formulation, two concepts are of special interest. The first is that of 'command', which carries with it the implication that the person giving the command has appropriate standing within a system of normatively-generated authority. As Gilbert notes, this makes the concept of a 'command' philosophically interesting, whereas 'there is little that needs [philosophical] explanation about uttering imperatives, yelling at someone ... and so on'. ${ }^{58}$ The second crucial concept is that of a 'joint commitment', which according to Gilbert is based on an understanding of the dynamics of social groups:

A social group is founded on one or more joint commitments of the parties. That gives the social group a substantial kind of unity, a unity perceived by its members, without whose appropriate understandings it cannot be. This particular species of perceived unity provides a basis for a range of phenomena that have been associated with an individual's identification with a group ... It thus accords with much that has been thought about social groups ... by social theorists and political philosophers. ${ }^{59}$

54 Ibid at 11.

55 M Gilbert, A Theory of Political Obligation (Oxford, Clarendon Press, 2006) 46: 'the "problem of political obligation" is a standard phrase, whereas the "problem of political authority" is not'.

56 WK Muir, Jr, Police: Streetcorner Politicians (Chicago, University of Chicago Press, 1977) discussed in Bottoms and Tankebe, above n 51 at 74-76.

57 Gilbert, above n 55 at 248-49.

58 Ibid at 246.

59 Ibid at 91 . To the researchers mentioned by Gilbert, one could add also 'empirical social psychologists'. For a classic text on 'normative social similarities and differences between people in their perceptions, cognitions, feelings and actions' within group settings, see JC Turner, Social Influence (Milton Keynes, Open University Press, 1991) 2. 
As Gilbert makes clear, a 'joint commitment' does not have to involve an actual contract. On that basis, it is reasonable to assume that, at least in most contemporary states, there is an implicit 'joint commitment' to the effect, roughly, that in order to maintain order the community needs a functioning police service. Moreover, in most states, while many people are aware of the imperfections of their police service, they do not think it is so dreadful that they owe no commitment to it. ${ }^{60}$

In light of Gilbert's analysis, we can usefully return to Williams' ' $A$ and B' example (above), and flesh it out with some imaginary narrative details. In a large English city, Alan and Brenda went to school together, and had a brief teenage romance before they went to separate universities and lost touch. A decade later, Alan is a police officer and Brenda, who was always interested in politics, has become a prominent young elected member of the city council. Late one winter evening, when Alan is on vehicle patrol, he notices a car veering substantially over the white line in the middle of the road before returning to the correct side. He signals the car to stop, explains to the driver why he has stopped her, and orders her to take a breathalyser test, only then realising that it is Brenda. He has therefore issued what Gilbert calls a 'command' to Brenda, and he would claim, if asked, that (in Williams' words) 'it would be wrong for B to fight back' ${ }^{61}$ Brenda, who has immediately recognised Alan, experiences considerable personal discomfort at being given an order by a former boyfriend. However, as a councillor she accepts the legitimacy of the police service, and she recognises that Alan has given a reasoned justification for ordering a breathalyser test. ${ }^{62}$ She realises, therefore, that she cannot reasonably refuse to obey Alan's order. This is because Alan, as a police officer, has the standing and the authority to give this order, and this public normative context transcends their personal relationship. The case therefore fulfils Gilbert's requirement (see above): ' $X$ has the standing to command $\mathrm{Y}$, subject to conditions $\mathrm{C}$, if and only if $\mathrm{X}$ and $\mathrm{Y}$ are subject to a joint commitment such that, in order to conform to

60 There are exceptions: for example, in the divided society of Northern Ireland at the beginning of the 'peace process', a high-profile independent review body reported that in 'meetings in strongly Catholic/Nationalist areas ... participants expressed strong criticism of the RUC [Royal Ulster Constabulary] and demanded a new police service', and in a survey 'less than $5 \%$ of Catholics said they had a lot of confidence in the police'. Even here, however, across Northern Ireland as a whole, 43 per cent of Catholics surveyed expressed 'overall satisfaction' with the police at that time: A New Beginning: Policing in Northern Ireland, Report of the Independent Commission on Policing for Northern Ireland (chairman: Rt Hon Christopher Patten) (London, The Stationery Office, 1999) 15.

61 Williams, above n 5 at 6.

62 In contrast to some other common law jurisdictions, in England and Wales the police do not have power to order breathalyser tests on a random basis. Under s 6 of the Road Traffic Act 1988, such a test can only be required where a constable 'reasonably suspects' that a driver has either committed a moving traffic offence, or has consumed alcohol or drugs. Evidence of erratic driving constitutes a sufficient ground for reasonable suspicion. 
it, Y must do what X says, subject to conditions C'.63 Williams' analysis is crucial, however, in insisting that one of the 'conditions C' must always be that the power-holder is able to respond adequately (as Alan could in this case) to a citizen's 'Basic Legitimation Demand'-that is, a demand by her that the power-holder should offer normatively appropriate reasons why the citizen must obey the command.

A further important point arises from this discussion. The inclusion within Williams' analysis of the need for a legitimation to be offered to every subject seems to go at least some way towards defusing the standard critique of empirical conceptions of legitimacy previously discussed. (Namely, that if a majority is content with the legitimacy of the power-holder, then the power-holder's legitimacy is assured, even if the power-holder is systematically mistreating a minority.) This is because, if legitimation has to be offered by the state to every subject, then in places like Dystopia (see above), where the state wishes to deport a minority en masse, this policy will need to be expressly argued for in normative terms to all members of the minority group. Moreover, in a contested decision of this kind, it will be a requirement of offering a legitimation to every subject that representatives of the state should be willing to listen carefully to the (almost certainly opposing) views of those over whom it is planning to exercise coercive control. Since, as everyday experience attests, it is easier to make a decision that is unfavourable to a given individual if one does not have to discuss that decision with him/her on a face-to-face basis, it follows that Williams' 'meeting the basic legitimation demand' principle constitutes, in Hinsch's terms, ${ }^{64}$ a partial normative brake within a basically empirical conception of legitimacy. However, it is not a complete brake, because the state would still be able to take coercive action against the minority (ie, deport them) after it has listened carefully to their representations; and on an exclusively empirical conception of legitimacy, it could call this action legitimate if it is democratically approved. ${ }^{65}$

We began this discussion by referring to the doctrine of 'policing by consent', so we now need to note that there is a subtle yet crucial difference between the state 'giving a legitimation to every subject' and every subject needing to consent to the state's use of power. We can illustrate the difference by reference to some events in an English high security prison in the early 1990s. This prison contained within it a small and dedicated 'Special Security Unit' (SSU), which was reserved for prisoners deemed to require

63 Gilbert, above n 55 at 248.

64 Hinsch, above $n 7$.

65 This analysis necessarily raises the question: 'who counts as a subject in discussions of this kind?' To consider this question fully would require a separate essay, but, in brief, Williams' answer is: 'anyone who is in [the state's] power, whom by its own lights it can rightfully coerce under its laws and institutions' (Williams, above n 5 at 4). 
the very highest levels of security. Prisoners in this unit objected, on grounds of privacy, to prison staff patrolling the small exercise yard attached to the SSU, and requested them to stop doing so. According to an official report, staff acceded to this request, because 'they had not felt welcome' in the yard. ${ }^{66}$ They relied on CCTV instead, but there was a known deficiency in the CCTV's coverage of the yard, and this became highly relevant in a subsequent high profile escape. Clearly, the prisoners had not consented to officers patrolling the yard, but could such patrolling have been more robustly defended as legitimate? There is little doubt that it could have been, provided that the patrolling was being carried out in accordance with normal professional standards (and there was no suggestion to the contrary). The prison staff could offer a reasonable legitimation to each prisoner as to why, on security and control grounds, it is necessary to patrol prison exercise yards, ${ }^{67}$ and a legitimation along these lines would have fallen squarely within the mainstream of shared values in British society. ${ }^{68}$

This analysis helps us to see that 'policing by consent' is in some ways an unfortunate phrase-the police do not, for example, need the 'consent' of organised crime groups when they are policing these groups' activities. What the phrase is trying to convey is, of course, the notion of legitimate policing. In line with Beetham's helpful formulation (see previous discussion), the concept of legitimate policing can be rephrased as policing where there is congruence between the system and the practices of policing, on the one hand, and the societal beliefs, values and expectations that provide its justification, on the other. ${ }^{69}$ Williams' concept of the basic legitimation demand then helps us to sharpen that formulation by insisting that the police must always be willing to offer justifications for their actions ('the system and the practices of policing') to each citizen with whom they interact. It is a tough requirement, but a necessary one.

\section{B. Williams and Weber}

An instructive contrast can be drawn between the approaches to legitimacy of Williams and of Weber. Like Williams, Weber claims that all politicallyconstituted states seek legitimation, but while for Williams this is a necessary

$66 \mathrm{~J}$ Woodcock, Report of the Enquiry into the Escape of Six Prisoners from the Special Security Unit at Whitemoor Prison, Cambridgeshire, on Friday 9th September 1994, Cmnd 2741 (London, Her Majesty's Stationery Office, 1994) 56.

67 Since exercise yards are normally outdoor facilities, they are in principle easier to escape from than cellblocks, and so require appropriate staff vigilance. Additionally, a staff presence can help to prevent physical conflicts between prisoners.

68 For a fuller discussion of this example, see R Sparks, AE Bottoms and W Hay, Prisons and the Problem of Order (Oxford, Clarendon Press, 1996) 329-36.

69 Adapted from Beetham, above n 4 at 11. 
condition of politics as opposed to terror (see above), for Weber it is an empirical observation. ('Experience shows that in no instance does domination voluntarily limit itself to the appeal to [citizens'] material or affectual or ideal motives as a basis for its continuance. In addition, every such system attempts to establish and to cultivate the belief in its legitimacy. ${ }^{70}$ ) Yet despite this similarity, the two authors differ crucially in what can be described as the 'standpoint' of their respective analyses. Williams insists that, precisely because it is seeking to exercise justified power, the state needs to offer a legitimation justification to each citizen; accordingly, within his analysis the standpoint of each citizen is central. By contrast, Weber approaches legitimacy primarily from the standpoint of power-holders, and their concern with securing assent to their rule. Accordingly, Weber defines legitimacy as 'the probability that to a relevant degree the appropriate attitudes [ie, acceptance of the validity of the power-holder's claim to be a valid authority] will exist, and the corresponding practical conduct [ie, obedience] ensues'. ${ }^{71} \mathrm{He}$ elaborates the point by making clear that these 'attitudes' and the corresponding 'conduct' can be motivated by many reasons:

Loyalty may be hypocritically simulated $\ldots$ on purely opportunistic grounds, or carried out in practice for reasons of material self-interest. Or people may submit from individual weakness and helplessness because there is no acceptable alternative. But these considerations are not decisive ... What is important is that in a given case the particular claim to legitimacy is to a significant degree ... treated as 'valid' [and] that this fact confirms the position of the persons claiming authority. ${ }^{72}$

As the italicised sentence shows, Weber's approach allows for the possibility of a stable domination, described as 'legitimate', in which the demands of power-holders are obeyed simply because the citizens realise that they are powerless and there is no alternative- that is, for what sociologists have described as 'fatalistic' reasons. ${ }^{73}$

We have argued elsewhere that Weber's approach is unsatisfactory, 'because it leaves the social scientist without any adequate means of distinguishing between obeyed legality ['fatalism'] and truly normative [empirical] legitimacy' ${ }^{74}$ In the context of policing, the difference between his

70 Weber, above n 3 at 213.

71 Ibid at 214. See further P Lassman, 'The Rule of Man over Man: Politics, Power and Legitimation' in S Turner (ed), The Cambridge Companion to Weber (Cambridge, Cambridge University Press, 2000).

72 Weber, above n 3 at 214 (emphasis added).

73 As David Lockwood has observed, in social conditions of entrenched social inequality it is not the case that 'widespread agreement on the ultimate values legitimating institutions is a prerequisite of social stability'; rather, in such contexts, a 'sufficient condition of order is simply that the structure of power, wealth and status is believed to be inevitable': see D Lockwood, Solidarity and Schism (Oxford, Clarendon Press, 1992) 43.

74 AE Bottoms and J Tankebe, 'Beyond Procedural Justice: A Dialogic Approach to Legitimacy in Criminal Justice' (2012) 102 Journal of Criminal Law and Criminology 119 at 130. 
conception and that of Williams can be vital. Imagine an oppressed ethnic minority who regularly receive aggressive, coercive and disrespectful policing, and who resent this. However, they do not protest much, or fight back, because of what they perceive to be their powerless position. (Sadly, this scenario is not very difficult to imagine.) According to Weber's definition, this is legitimate domination, but for Williams it is not because the basic legitimation demand is not met. Does this matter in practice (as opposed to in academic articles)? In brief, it does, for two main reasons. First, such an ethnic group will not readily provide information to the police, whereas if the policing were more in line with the basic legitimation demand, more information would probably be supplied. Second, there will probably be a significant attitudinal difference between members of a Weber-influenced and a Williams-influenced police service. The former will consider themselves legitimate as long as they are obeyed, and not concern themselves too much with how citizens regard their policing style. The latter, by contrast, will always recognise that they are 'one lot of people' who hold significant power over 'another lot of people'; that reasons always need to be given as to why their power is justified; and that citizens have reason to make some 'basic legitimation demands' about how members of their police service should justify their authority (and therefore how they should behave). Accordingly, a Williams- influenced police service will be more likely to generate a managerial strategy that takes seriously the interests of the policed; and is easy to see that this is likely to result in better local policing.

Although Williams' approach is to be preferred to that of Weber, it is nevertheless a weakness of his analysis that he does not mention fatalism. Serious consideration of fatalism makes one recognise the falsity of Williams' view (see above) that if power is not justified the result is always terror; another possible result of unjustified power can be a coercive social order breeding fatalism. But in conditions of fatalism, other aspects of Williams' analysis still hold. For example, in fatalism overweening policing can very easily become part of the problem of order, not part of the solution. ${ }^{75}$ Moreover, conditions of fatalism are a good example of the general point made by Williams that an answer to the first political question is a necessary, but not necessarily a sufficient, condition for a state to achieve legitimacy. ${ }^{76}$

75 Sparks et al, above n $68 \mathrm{ch} 6$, in their study of high security prisons, describe conditions in a 'Vulnerable Prisoner Unit' (VPU) reserved for prisoners (such as sex offenders) who would face hostilities and perhaps injury from other prisoners if they were located on a main prison wing. Naturally, such prisoners felt themselves to be in a weak position, and they therefore fatalistically accepted the prison regime. Prison staff, on being transferred to the VPU from the main prison, sometimes acted improperly, as one prison staff member explained: 'they've had years and years working up on the main wings, and they get down here and think ... "I don't believe this ... I shouted at him and he never shouted back" ... then one thing develops into another, and ... the power can go to your head easy' (at 214).

76 Williams, above n 5 at 3. 


\section{SUPPLEMENTING THE BASIC LEGITIMATION DEMAND: THE ROLE OF THE IMPARTIAL SPECTATOR}

Throughout his chapter on legitimacy, Williams shows a degree of preoccupation with the relationship between legitimacy and liberalism. This is an illuminating discussion, but it also reveals a need to supplement the analysis concentrated on the basic legitimation demand.

\section{A. The Basic Legitimation Demand and Liberalism}

Williams summarises his conclusions on liberalism and the basic legitimation demand by saying (in the form of an equation) that, 'very roughly speaking', 'Legitimacy + Modernity = Liberalism'. ${ }^{77}$

What does he mean by this? His thesis is that in contemporary societies, the historical conditions that we find ourselves in, together with the concept of the basic legitimation demand, 'permit only a liberal solution; other forms of answer are unacceptable'. He argues that, at least in part, this is because in a post-Enlightenment era 'other supposed legitimations are seen to be false and in particular ideological'. ${ }^{78}$ Williams does not specify what these 'other supposed justifications' are, but they would certainly include, for example, the claim that kings have a divine right to rule-a concept which those supporting 'modernity' spent considerable time and effort in contesting in the seventeenth and eighteenth centuries. Williams insists, however, that the 'unacceptability' of non-liberal solutions arises only from contemporary political conditions, and not because 'some liberal conception of the person, which delivers the morality of liberalism, is or ought to be seen as correct'. ${ }^{79}$

In making these comments, Williams is of course aware that not all contemporary states fully endorse the principles of liberal democracy. Hence, we find him asking how we should assess a society where there is, apparently, widespread acceptance of a theocratic regime, and/or of laws promoting a subordinate role for women. It is reasonable, he thinks, in such a context to ask whether 'the acceptance of these ideas can ... be plausibly understood as an expression of the power relations that are in question'- that is, whether the dominant group has deliberately inculcated a belief system in order to sustain its own domination. ${ }^{80} \mathrm{He}$ accepts, however, that this might not be

77 Ibid at 10 .

78 Ibid at 8 .

79 Ibid.

80 Ibid at 27 . Williams says that this might sound 'improbably extreme'; but he could have cited evidence from some religious cults, where this kind of ideological manipulation has sometimes been shown to have taken place. 
the case, and therefore that the widespread acceptance of non-liberal ideas in a given society might indeed be genuine. Although he does not make this further point, the implication of this argument must be that in principle, and despite the current ideological dominance of liberal-democratic ideas, a contemporary non-liberal state could be regarded as fulfilling Beetham's three sociological criteria for legitimate government, namely lawfulness, shared beliefs and expressions of consent. ${ }^{81}$

Ultimately, therefore, Williams leaves us with a degree of unresolved tension in relation to these issues. This tension can also be directly mirrored in the world of policing. For example, it is certainly the case that - to an increasing extent-police services throughout the world are being expected to take account of human rights declarations and conventions, in line with Williams' contention that 'Legitimacy + Modernity = Liberalism'. Yet police practices that do not conform with human rights standards continue to be regularly applied in many states, sometimes with explicit or tacit official approval. ${ }^{82}$ We have ourselves encountered senior police officers in a particular jurisdiction who were open in their espousal of torture as an appropriate tool within police interrogations, and who believed that this practice was supported by the population in their state (and was therefore empirically legitimate, on Hinsch's definition). ${ }^{83}$

The tension described in the previous paragraph undoubtedly raises some very difficult issues. We believe, however, that some further understanding of these issues can be obtained by examining Amartya Sen's approach to the concept of justice. ${ }^{84}$

\section{B. The Test of the Impartial Spectator}

In July 2009, 13 women, all wearing trousers, were arrested in a Sudanese restaurant for the offence of 'disturbing the public order by dressing indecently' under the Sudanese criminal code, which is based on Islamic Sharia law. Most of the arrestees pleaded guilty, and were promptly flogged, each receiving 10 lashes. However one woman, a Sudanese journalist called Lubna Ahmed al-Hussein, was told that she would not be prosecuted because she was working for the United Nations, in a post that carried diplomatic immunity. She then deliberately resigned her UN post in order to be able to stand

81 Beetham, above $\mathrm{n} 4$ at 20 .

82 See for example, R Wahl, 'Justice, Context, and Violence: Law Enforcement Officers on Why They Torture' (2014) 48 Law and Society Review 807; B Jauregui, 'Law and Order: Police Encounter Killings and Routinized Political Violence' in I Clark-Deces (ed), A Companion to the Anthropology of India (Chichester, Wiley-Blackwell, 2011); J Belur, Permission to Shoot? Police Use of Deadly Force in Democracies (London, Springer, 2010).

83 Hinsch, above $\mathrm{n} 7$.

84 Sen, above $\mathrm{n} 6$. 
trial, and she told the BBC that she wanted 'a public flogging to make a point about the treatment of women in Sudan'; she also sent out 500 invitations to various people to come and witness her lashing. However, when she was eventually tried, she was sentenced not to a flogging but to a fine. She refused to pay the fine on the grounds that this would legitimate the conviction, and so she was sent to prison. However, the fine was very soon paid on her behalf (but against her wishes) by an association of journalists, and she was freed. ${ }^{85}$

In this case, there was an explicit contestation of the legitimacy of the police and prosecutors' interpretation of the Sudanese indecency law. In this contest, two views of justice were invoked. The first was rooted in Sharia law, which claims the allegiance of all Muslims. However, Lubna Ahmed Al-Hussein, herself a Muslim, rejected the view that women wearing trousers has anything to do with either indecency or Islamic religion, and made it clear that in her view the prosecution was motivated by a worldview that inappropriately espoused the discriminatory treatment of women. This view, of course, was much closer to liberal assumptions than was the view of the Sudanese prosecuting authorities. Not surprisingly, the case quickly generated international interest, and a flurry of statements supporting Lubna's cause emerged from a variety of liberal-oriented organisations. Rather similar sequences of events have occurred in subsequent dress-related prosecutions of women in Sudan, and in the press reports of these cases the previous experience of Lubna Ahmed Al-Hussein is regularly cited. ${ }^{86}$

We have told this story as an illustration of the way in which contestations of legitimacy frequently develop. A state has one set of practices; these are challenged as unjust and illegitimate; people within the state, and sometimes outside it, take positions one way or the other; the issue is revisited in subsequent cases of a similar nature; citizens' views often change as the debates develop; sometimes, but by no means always, the law (or a given set of institutional practices) is modified.

Amartya Sen's theory of justice is rooted in this kind of empirical reality. He makes clear at the beginning of his book that his main aim is 'to address questions of enhancing justice and removing injustice', and that this makes his theory different in significant respects from other 'pre-eminent theories of justice in contemporary moral and political philosophy', ${ }^{87}$ notably that of John Rawls. ${ }^{88}$ Two of these differences are of special interest in the present

85 AH Fadlalla, 'State of Vulnerability and Humanitarian Visibility on the Verge of Sudan's Secession: Lubna's Pants and the Transnational Politics of Rights and Dissent' (2011) 37 Signs 159. For the quotation to the BBC, see LW Sherman, 'Defiance, Compliance and Consilience: A General Theory of Criminology' in E McLaughlin and T Newburn (eds), The Sage Handbook of Criminological Theory (London, Sage Publications 2012) 361 at 362.

86 See for example Zeinab Mohammed Salih, 'Outrage as Nine Sudanese Women Face 40 Lashes for Wearing Trousers’ Guardian Africa Network (14 July 2014).

87 Sen, above $\mathrm{n} 6$ at ix.

88 Rawls, above n 20. 
context. First, Sen's focus is on the 'actual lives ... that people are able to lead', as well as on the social institutions designed to promote justice. ${ }^{89}$ Second, Sen has no interest in searching for the characteristics of perfectly just societies. Instead, his method is comparative. He advocates a reasoned comparison of the qualities of justice contained in two or three approaches to policy, or to a particular decision. Arising out of this comparison, there is then a choice of the option that is the most just in all the circumstances. ${ }^{90}$

Clearly, Sen's is a 'realist' perspective, and in that respect it has much in common with the approach of Bernard Williams previously described. (Their substantive foci are different-respectively justice and legitimacybut the intellectual approach is similar). That commonality has led us to be interested in the possibility that Sen's theorisation might be utilised to complement Williams' approach to the study of legitimacy.

Of particular interest in this regard is Sen's approach to the process of comparing policy options-a process in which he places much emphasis on both the importance and the complexity of reasoned argument. His discussion is too rich to be easily summarised here, but we want to focus on one topic in particular, that of impartiality in decision-making. Here, Sen calls in aid the work of Adam Smith in his Theory of Moral Sentiments:

We can never survey our own sentiments and motives, we can never form any judgment concerning them; unless we remove ourselves, as it were, from our own natural station, and endeavour to view them at a certain distance from us. But we can do this in no other way than by endeavouring to view them with the eyes of other people, or as other people are likely to view them..$^{91}$

This is Smith's concept of the 'impartial spectator'; and Sen claims that in developing his theory of justice he is drawing upon and 'extending' Smith's concept. ${ }^{92} \mathrm{He}$ then draws an instructive contrast between this methodological

89 Sen, above n 6 at xi. This focus led Sen to develop the so-called 'Capabilities Approach', now sometimes called the Human Development Approach: ibid at chs 11-13; also MC Nussbaum, Creating Capabilities: The Human Development Approach (Cambridge MA, Harvard University Press, 2011).

90 A crucial feature of Sen's preference for a comparative approach is his 'rejection of the belief that questions of value can have only one right answer': ibid at $12 \mathrm{n}$. He illustrates this point (ibid at 12-15) with an engaging tale of three children quarrelling over which of them should possess a flute, given that $\mathrm{A}$, who is poor, has many fewer things to play with than $\mathrm{B}$ and $\mathrm{C}$; B has made the flute; and $\mathrm{C}$ is the only one who currently knows how to play it.

91 A Smith, The Theory of Moral Sentiments (Oxford, Clarendon Press, 1976) 110; cited in Sen, above $\mathrm{n} 6$ at 125 .

92 Sen, above $n 6$ at 134 . There is a significant literature that is critical of Sen's understanding of Adam Smith. This literature is fully referenced by Bréban et al, who helpfully point out that Smith's conceptualisation 'is concerned with individual deliberation, whereas Sen is concerned with collective deliberation'. (L Bréban, M Gilardone and B Walraevens, A Missing Touch of Adam Smith in Amartya Sen's Public Reasoning: The Man Within for the Man Without (Paris, Laboratoire d'Économie Dionysien Université Paris 8, Working Paper No 55, 2014) 11). In this chapter, we work simply with the concept of the impartial spectator as presented by Sen. 
device and that used by John Rawls, in which, famously, people decide the ideal principles of justice for a hypothetical society when they are behind a 'veil of ignorance' which prevents them from knowing whether, in that society, they will be rich or poor, male or female, healthy or disabled, etc. ${ }^{93}$ The veil of ignorance is, of course, a methodological strategy that encourages impartial judgements; but, as Sen points out, those judgements are made by people who will be part of the society once it is established ('closed impartiality'). By contrast, Sen's concept of the impartial spectator explicitly allows the views of persons from other societies and cultures to be considered and weighed as part of the reasoning process ('open impartiality'). ${ }^{94}$

It is this feature of Sen's methodological approach that makes it valuable in the context of the debate initiated by Bernard Williams, and exemplified in the case of Lubna Ahmed Al-Hussein, concerning the relationship between legitimacy and liberalism. It seems clear that there are some contemporary states, and some contemporary police services, which have successfully legitimated themselves while adhering to values other than those of mainstream liberal-democratic political theory. In that sense, Williams' equation ('Legitimacy + Modernity $=$ Liberalism') is incorrect as a universal statement. But, as the case of Lubna Al-Hussein vividly demonstrates, there remains an important truth in Williams' formulation, which is that, in contemporary societies, liberal values are always available as a powerful conceptual tool that can be deployed in debates and contestations about legitimacy in any society.

We would also argue that the concept of the impartial spectator has a wider relevance to the themes of this chapter, beyond the debate about liberalism, modernity and legitimacy. We highlight two further possible applications of the concept, one relating to the macro level, and one to the micro. The first of these is of particular importance to our overall argument.

To discuss the macro-level issue, let us return to a problem previously identified, namely the difficulties that can arise from adopting an exclusively empirical approach to the study of legitimacy. At the end of our discussion of this topic (see section I.A above), we advocated the adoption of a primarily empirical approach to legitimacy, but we also argued that-to avoid the 'Dystopia' problem-this approach should be located within a set of inalienable normative commitments. We did not then discuss how this could be achieved, but an obvious model is to be found in the entrenchment of the Bill of Rights within the constitution of the United States, and of the European Convention of Human Rights within the national laws of most European countries. A provision of this kind would back up, and give additional substance to, the partial 'normative brake' that we identified above, arising

93 Rawls, above n 20 at 12, 136-42.

94 Sen, above n 6 ch 6 (on 'Closed and Open Impartiality'). 
from Williams' identification of the need for the state to provide a justified legitimation of its uses of power to every citizen. It would provide what we described at the end of section I.A (above) as a 'bedrock of inalienable normative commitments' on which more empirical analyses of legitimacy could be built.

But suppose there is a state where there is currently no entrenched 'Bill of Rights'-style commitment, yet its legislature has been persuaded that it should adopt a model of this type. How should it go about creating the content of the entrenched provisions? Here, the concept of the impartial spectator seems to have much merit as a methodological device-not least because this concept explicitly requires its users to look outside their own cultural framework. That is not to say, of course, that it will be sensible for any given state or cultural group to disregard the accumulated wisdom available within that community. ${ }^{95}$ Such sources of wisdom should certainly be drawn upon, yet they should also be appropriately tested by considering insights from elsewhere, in a reasoned process of 'open impartiality', as advocated by Sen.

At a more theoretical level, the complementary insights of Williams' basic legitimation demand and Sen's impartial spectator can be characterised in terms of subjectivity and objectivity. Williams insists that 'the [basic legitimation demand] ... requires a legitimation to be given [by the state] to every subject', ${ }^{96}$ which implies that each citizen can formulate a basic legitimation demand. This inevitably introduces an element of subjectivity and empirical difference into the dialogues relating to the basic legitimation demand, although, as we have seen, an adequate legitimation can be offered without requiring the consent of each individual or group. In consequence, Williams' theorisation of the basic legitimation demand is ultimately, in Hinsch's terms, empirical, ${ }^{97}$ and to be fully adequate it requires some objective normative buttressing. Sen's impartial spectator strategy seems a good way of providing that normative buttressing.

Turning now from the macro to the micro level, the concept of the impartial spectator has, we believe, some practical relevance in relation to the (rather too frequent) ethical failures of police leaders. In an important psychological study, Terry Price has argued that the ethical failures of societal leaders are very often not volitional but cognitive. ${ }^{98}$ 'Volitional' ethical

95 One might think this is improbable, but see Brian Tamanaha's description of how, as an American expatriate working as a young lawyer in Micronesia, he discovered that Micronesian 'customs and values could hardly have been more different from the legal system and its norms', because Micronesian law had been 'transplanted in its entirety from the United States': BZ Tamanaha, A General Jurisprudence of Law and Society (Oxford, Oxford University Press, 2001) xi.

96 Williams, above n 5 at 6.

97 Hinsch, above $\mathrm{n} 7$.

98 T Price, Understanding Ethical Failures in Leadership (Cambridge, Cambridge University Press, 2006). 
failures, in Price's conceptualisation, occur when someone wilfully chooses to act wrongly, usually for reasons of self-interest or personal gain; he or she is fully aware that the act is wrong. 'Cognitive' ethical failures, by contrast, occur when people persuade themselves that the rules do not apply to them, or that they are exempt from them, perhaps because they perceive themselves to be a 'special person' without whom the organisation would struggle, or because they think the particular situation requires them to 'bend the procedural rules' a little, in order to achieve an obviously desirable outcome. A recent exploratory research study, carried out for the College of Policing in England and Wales, has found that among very senior police officers investigated for ethical failures, 'cognitive failures' very significantly outnumbered 'volitional failures'. ${ }^{99}$ By definition, a 'cognitive failure' should be open to correction by a process of reasoning; and an 'impartial spectator' should be able to provide that reasoning. Accordingly, it would seem that putting in place consultation procedures that could mimic the concept of the impartial spectator should reduce ethical failures among senior police officers-and therefore, probably, improve police legitimacy.

From the above discussion, we can reasonably conclude that, in both its micro and its macro applications, the concept of the impartial spectator is a useful methodological device for state authorities and police services to utilise when they think seriously about police legitimacy.

\section{RESPONDING JUSTIFIABLY TO THE BASIC LEGITIMATION DEMAND}

The principal remaining task of this chapter is to attempt to suggest some content for justifiable police responses to the basic legitimation demands of those who are policed. We have seen that, according to Williams, citizens are entitled to 'ask what the nature of state's protection and its price are to be, and they will want a reasonable reply'. ${ }^{100}$ The challenge is to provide an analysis of the kinds of response that will normally satisfy citizens as being a justifiable legitimation, while also recognising that such responses might well vary in different cultural and political conditions.

Aspects of this topic have been of interest to researchers and theorists in criminology for the last quarter of a century, albeit not in the context of Williams' theorisation. Given this, we shall first sketch, in broad-brush terms, two different theoretical contributions within this literature, as a prelude to a more specific consideration of the possible content of justifiable responses to the basic legitimation demand in relation to policing.

99 G Hales, T May, J Belur and M Hough, Chief Officer Misconduct in Policing: An Exploratory Study (Ryton-on-Dunsmore, College of Policing, 2015).

100 Hawthorn, above n 50. 
Criminological scholars came late to the serious study of criminal justice legitimacy, and the first major text on this subject was Tom Tyler's seminal Why People Obey the Law, published in $1990 .{ }^{101}$ This has been followed by many other empirical studies and theoretical analyses in the same tradition, both by Tyler and by others. Together, these studies have generated a very impressive, and mostly consistent, body of knowledge, usually referred to as 'procedural justice theory'. ${ }^{102}$

Tyler's initial main interest was in the topic of legal compliance, as the title of his 1990 book makes clear. At a time when 'much traditional social [science was] built on the assumption that behavior is motivated by rewards and punishments in the external environment', ${ }^{103}$ Tyler produced strong evidence from survey data of the relevance to compliance of normative factors, especially 'procedural justice', which-it was shown-generated attributions of legitimacy, leading to compliance. In later analyses, procedural justice was perceived to have two distinct but interconnected strands. ${ }^{104}$ The first, akin to the well-developed administrative law concept of 'natural justice', ${ }^{105}$ is concerned with issues such as whether, within a contentious incident, a citizen is allowed by a power-holder to express his/her point of view, whether the decision-maker acts in a professional manner and appears competent to deal with the issues involved, and so on. This strand is termed the quality of decision-making. The second strand, by contrast, is more personal, and embraces a set of issues focused upon whether the individual dealt with by the authority figure has been treated with appropriate dignity and recognition as a person. This strand is called the quality of treatment. Studies show that both strands need to be in place if full procedural justice is to be delivered.

A further important insight developed by procedural justice theory has been the concept of the 'teachable moment'. In his original study, Tyler commented that when people encounter legal authorities, 'more is at stake' than the specifics of that particular encounter, because 'the procedures experienced are viewed as information about the group that the authority represents'. ${ }^{106}$ In other words, if a driver is stopped by

101 TR Tyler, Why People Obey the Law (New Haven, Yale University Press, 1990); reissued with a new Afterword by Princeton University Press, 2006. Page numbers of the main text are the same in both editions.

102 Some of the main contributions are: TR Tyler and YJ Huo, Trust in the Law (New York, Russell Sage Foundation, 2002); J Sunshine and TR Tyler, 'The Role of Procedural Justice and Legitimacy in Shaping Public Support for Policing' (2003) 37 Law and Society Review 513; J Jackson, B Bradford, E Stanko and K Hohl, Just Authority? Trust in the Police in England and Wales (London, Routledge, 2012).

103 Tyler, above n 101 at 20.

104 See for example TR Tyler, 'Procedural Justice, Legitimacy, and the Effective Rule of Law' (2003) 30 Crime and Justice: A Review of Research 283.

105 W Wade and CF Forsyth, Administrative Law 11th edn (Oxford, Oxford University Press, 2014) 373-474.

106 Tyler, above n 101 at 175 . 


\section{Anthony E Bottoms and Justice Tankebe}

Constable Smith, in her mind she did not simply encounter Constable Smith; she encountered a police officer, and she will tend to treat the behaviour of Constable Smith as providing information about the police service as a whole. Hence, in a later work, Tyler advised that 'every encounter that the public have with the police ... should be treated as a socialising experience that builds or undermines legitimacy. Each contact is a "teachable moment" in which people learn about the law and legal authorities'. ${ }^{107}$ This insight can be linked with Margaret Gilbert's analysis of authority and 'standing', as previously described. For Gilbert, it will be recalled, ' $\mathrm{X}$ has the standing to command $\mathrm{Y}$, subject to conditions $\mathrm{C}$, if and only if $\mathrm{X}$ and $\mathrm{Y}$ are subject to a joint commitment'. ${ }^{108}$ However, if X's colleagues, $\mathrm{P}$ and $\mathrm{R}$, last week treated $\mathrm{Y}$ very disrespectfully when they stopped and searched him, then $\mathrm{Y}$ will probably be less inclined to believe in any 'joint commitment' with the local police service-and so X's standing (or political authority) in his encounter with $\mathrm{Y}$ will have been damaged by the behaviour of $\mathrm{P}$ and $\mathrm{R}$. There is indeed empirical evidence confirming that citizens often interpret their encounters with the police in light of previous experiences with police officers-sometimes including experiences in other countries. ${ }^{109}$

Although it has been dominant, procedural justice research and theory has not been the only strand within the study of legitimacy in criminal justice contexts. Building on some of this other work, much of which has been carried out in prisons, ${ }^{110}$ the two authors of this chapter proposed in 2012 that the study of legitimacy in criminal justice contexts needed to move 'beyond procedural justice' as the dominant focus of scholarly attention, although we fully endorsed the empirical strength and the theoretical insights of the procedural justice literature. ${ }^{111}$ We utilised

107 TR Tyler, 'Trust and Legitimacy: Policing in the USA and Europe' (2011) 8 European Journal of Criminology 254 at 257.

108 Gilbert, above n 55 at 248.

109 PAJ Waddington, K Williams and M Wright, 'Dissension in Public Evaluations of the Police' (2015) Policing and Society 212; D Harkin, 'Police Legitimacy, Ideology and Qualitative Methods: A Critique of Procedural Justice Theory' (2015) 15 Criminology and Criminal Justice 594.

110 The first major analysis of legitimacy in relation to prisons was offered by Sparks et al, above n 68. More recent work has been produced especially by Alison Liebling: see A Liebling with H Arnold, Prisons and their Moral Performance: A Study of Values, Quality, and Prison Life (Oxford, Oxford University Press, 2004); also, summarising later work, A Liebling, 'Appreciative Inquiry, Generative Theory and the "Failed State” Prison', in J Miller and WR Palacios (eds), Qualitative Research in Criminology (New Brunswick NJ, Transaction Publishers, 2015).

111 Bottoms and Tankebe, above $\mathrm{n}$ 74. We also cited with approval (at 146) a comment by David Smith that, at this stage in the development of research on legitimacy in criminal justice, care was needed not to infer 'that procedural justice is the sole or central foundation of legitimacy in all societies at all stages of development': D Smith, 'The Foundations of Legitimacy' in TR Tyler (ed), Legitimacy and Criminal Justice (New York, Russell Sage Foundation, 2007) 30 at $31-32$. 
Beetham's conceptualisation of the criteria of legitimacy, and especially his first two criteria of lawfulness and shared values, as a central focus of our approach. As regards shared values, we argued that both procedural fairness and distributive fairness could be seen to be important shared values in relation to criminal justice legitimacy, at least in many situations. Additionally, we agreed with Beetham's view (to be discussed more fully shortly) that 'effectiveness' is an important shared value when assessing state legitimacy. ${ }^{112}$ As regards lawfulness, we were further persuaded by Beetham's view that a 'first condition of legitimacy' is that, in a state, power must be 'acquired and exercised in accordance with established rules'. ${ }^{113}$ Accordingly, we suggested a fourfold conceptualisation of the potential components of criminal justice legitimacy, as viewed by those subject to state power, namely: procedural justice, distributive justice, effectiveness and lawfulness. Two later empirical analyses, based on data from England, Ghana and the United States have supported this fourfold conceptualisation. ${ }^{114}$

In the same paper, we also proposed the adoption of an explicitly dialogic conception of legitimacy. We argued that legitimacy is an ongoing dialogue, which begins with power-holders making a claim to exercise legitimate authority. Those without power (whom we called 'audiences') might respond to this claim, power-holders might adjust their claims in the light of audience responses, and so on. Adoption of this view requires one to be alert to the legitimations offered by power-holders, the attributions of legitimacy (or otherwise) made by audiences, and the interactive relationship between them. We were not aware, when we wrote that paper, of Bernard Williams' work on legitimacy, but it will be clear from the discussion in this chapter that his valuable concept of the 'Basic Legitimation Demand' is wholly congruent with a dialogic view of legitimacy; indeed, it enhances our original conception of the 'dialogue' by pointing out that audiences may make reasonable demands on power-holders as to the kinds of legitimations that they (the power-holders) might justifiably offer within the dialogue. A further important feature of the dialogic metaphor is that a single power-holder may need to address several different audiences (the rich and the poor; different ethnic groups; etc); also, audiences may make a significant differentiation in their assessments of the legitimacy of different power-holders (for example, within the police service, the local neighbourhood police and the

112 Bottoms and Tankebe, above n 74 at $146-47$.

113 Beetham, above $\mathrm{n} 4$ at 64 .

114 J Tankebe, 'Viewing Things Differently: Examining the Dimensions of Public Perceptions of Police Legitimacy' (2013) 51 Criminology 103; J Tankebe, M Reisig and XA Wang, 'A Multidimensional Model of Police Legitimacy: A Cross-Cultural Assessment' (2016) 40 Law and Human Behavior 11. 


\section{Anthony E Bottoms and Justice Tankebe}

specialist drugs squad). ${ }^{115}$ Thus, there can be many different dialogues happening simultaneously. ${ }^{116}$

In light of this background, what can be said-as regards police legitimacy-about the content of justifiable responses to the basic legitimation demand? All modern states have created some version of a public police force/service (or forces/services) within their borders, so the basic argument providing a legitimation for the existence of a police service is perhaps not too difficult to make. However, most publics will, rightly, not give their police services carte blanche to act as they wish. We believe that the fourfold conceptualisation of 'audience legitimacy' that we identified in our 2012 paper might provide a reasonable description of the main requirements that operational policing must usually satisfy if it is to provide a justifiable response to the basic legitimation demand, and we shall therefore use this framework as the basis for the remaining discussion in this section. We shall focus especially on the normative dimensions of each of the four suggested requirements, considering why each might be of relevance within realist discussions in which 'what we acknowledge as legitimate, here and now, is what, here and now, makes sense as a legitimation of power as authority'; and remembering also that such discussions 'will be engaged, first-order discussions using our moral, social, interpretive and other concepts'. ${ }^{117}$ Precisely which 'moral, social, interpretive and other concepts' will be deployed is of course a contingent matter, varying in different specific contexts, but our suggestion is that there are good normative reasons, supplemented by empirical evidence, to support the view that procedural justice, distributive justice, effectiveness and lawfulness will often be relevant issues in these 'engaged, first-order discussions'.

One further preliminary comment is necessary. Given that it is not too difficult to provide a basic justification for the existence of a police service, and given also that many citizens have only very limited contact with police officers, in practice withdrawal of public support will mostly arise when the police service in a given state or local area fails to act in accordance with the public's, or the political elite's, view of how a police service should behave. Thus, substituting 'legitimacy' for 'justice', there is merit in JR Lucas' suggestion that 'we should follow the example of Aristotle 118

115 For later research providing evidence for this kind of differentiation, see Waddington et al, above n 109 .

116 Tom Tyler and Jonathan Jackson, in a chapter written partly in response to our 2012 paper (above, $\mathrm{n}$ 74) commented that 'the idea that legitimacy is dynamic and interactive' was 'the most important part' of that paper. They also agreed in principle that legitimacy could include dimensions other than procedural justice, but they cautioned that 'the degree to which we move beyond procedural justice is ultimately an empirical issue': T Tyler and J Jackson, 'Future Challenges in the Study of Legitimacy' in Tankebe and Liebling, above n 25 at 94.

117 Williams, above $\mathrm{n} 5$ at 11 .

118 Aristotle, The Nicomachean Ethics, translated by D Ross and edited by L Brown (Oxford, Oxford University Press, 2009) 80. 
and adopt a negative approach, discovering what justice is by considering on what occasions we protest at injustice or unfairness'. ${ }^{119}$ Following this advice, a key question becomes: why do police services tend to lose legitimacy if their police officers act unfairly (procedurally or distributively), or perform their duties ineffectively, or behave unlawfully?

\section{A. Procedural Justice}

Procedural justice (or procedural fairness) has been discussed above, and can be defined as the fairness of the processes employed to reach specific outcomes or decisions; it includes both the quality of decision-making and the quality of treatment. There is no doubt about its empirical importance in relation to police legitimacy; indeed, a powerful conclusion from the existing empirical research is that, when they make overall normative judgements about policing, citizens often prioritise procedural fairness (how they are treated) over the perceived favourability or fairness of the outcome of their encounter with the police. ${ }^{120}$

Given the normative focus of this chapter, we need to ask why procedural justice appears to be so empirically important? The most plausible answer is, stated simply, that when police actions demonstrate a recognition of an individual's rights ('quality of decision-making') and his/her humanity ('quality of treatment'), then that individual feels valued. This answer was first proposed by Lind and Tyler in 1988, and they named it the 'group value model'. ${ }^{121}$ Tyler later explained it in the following way in relation to one aspect of the 'quality of decision-making' (willingness to listen):

People value their participation in organizations and the opportunities that it provides to affirm their status within the group ... The willingness of the authority to listen to them and consider their arguments is a recognition of their social standing. If people are not allowed to express their views, they are being denied signs of their standing within the group, as well as opportunities for interaction with authorities that lead to positive beliefs about membership in the group. ${ }^{122}$

Tyler went on to argue that similar issues apply in relation to 'quality of treatment', where, for example, when 'the police harass members of minority groups $[$ or] the poor ... they are communicating to those groups that they have marginal ... status' within society. ${ }^{123}$

119 JR Lucas, On Justice (Oxford, Clarendon Press, 1980) 4.

120 TR Tyler and J Fagan, 'Legitimacy and Co-operation: Why Do People Help the Police Fight Crime in their Communities?' (2008) 6 Ohio State Journal of Criminal Law 231.

121 EA Lind and TR Tyler, The Social Psychology of Procedural Justice (New York, Plenum, 1988).

122 Tyler, above n 101 at $175-76$

123 Ibid at 176 . 


\section{Anthony E Bottoms and Justice Tankebe}

Interestingly, the group value model seems to have some potential links to Axel Honneth's philosophical work on the 'recognition' of individuals, ${ }^{124}$ although as far as we know these links have not yet been explored in the literature on procedural justice. ${ }^{125}$ As Christopher Zurn explains, Honneth's 'moral and social theories are founded upon the thesis that personhood is essentially constituted intersubjectively'; and from this base, Honneth postulates that there are 'three forms of intersubjective recognition-love, legal relations and solidarity'-that are vital for healthy human development. ${ }^{126}$ These three forms of recognition in turn correspond 'to three forms of practical self-understanding' by the individual subject, namely 'self-confidence, self-respect and self-esteem'. ${ }^{127}$ In the present context, it is the second and third of these forms of recognition that are of particular interest. Respectively, these can be summarised as follows:

[For Honneth] individuals gain a sense of self-respect only through the individual rights that are granted to members of a legal community ... When acknowledged as bearers of legal rights by the other members of their community through their legal status, individuals are able to gain a sense of self-respect, a sense of their inherent dignity as free and equal among others.

Persons ... are positively recognized through the social esteem expressed in solidaristic relations with others ... [E]steem relations extend as far as those who share the same substantive ethical values concerning what is socially worthy ... (what Honneth calls 'communities of value') ... the paradigmatic form of disrespect [for esteem relations is] cultural denigration and insult to ways of life. ${ }^{128}$

These potential links between Honneth's conceptualisation and procedural justice theory clearly require more detailed examination, but the resonances are intriguing.

\section{B. Distributive Justice}

In a memorable passage, Dennis Wrong has claimed that

the problem of order is a ... transhistorical problem rooted in inescapable conflict between the interests and desires of individuals and the requirements of society: to

124 A Honneth, The Struggle for Recognition: The Moral Grammar of Social Conflicts, translated by J Anderson (Cambridge, Polity Press, 1995).

125 However, Honneth's concepts of recognition and misrecognition were identified as 'core themes in the analysis' in Liebling et al's ethnographic study of the regime of a high security prison in England: A Liebling, H Arnold and C Straub, An Exploration of Staff-Prisoner Relationships at HMP Whitemoor: 12 Years On (London, Ministry of Justice, 2011).

126 CF Zurn, Axel Honneth: A Critical Theory of the Social (Cambridge, Polity Press, 2015) 24,28 .

127 Ibid at 28 .

128 Ibid at 34, 39-40. 
wit, the pacification of violent strife ... and the secure establishment of cooperative social relations making possible the pursuit of collective goals. ${ }^{129}$

This 'inescapable conflict' between individual desires and the needs of the collectivity inevitably leads to debates (or worse) about how various goods and services are to be distributed within the collectivity. Such debates can be readily seen in action by watching any group of children at play. Accordingly, it is no surprise that the concept of 'distributive justice' can be traced back historically as far as Aristotle, who defined it as 'manifested in distributions of honour or money or the other things that fall to be divided among those who have a share in the constitution'. ${ }^{130}$

In the context of criminal justice, the outcomes of cases are one manifestation of distributive justice or injustice. We have noted above the common finding, in the general population surveys reported in the procedural justice literature, that how people are treated in their encounters with officials (procedures) seems to shape overall judgements of legitimacy more than the outcome of the encounter. However, this kind of result is not replicated in all contexts. One reason for this is that, as Tyler himself noted in his original publication, in surveys of the general population citizens might well 'lack the information to judge consistency' of outcomes. ${ }^{131}$ Also, of course, the more significant the outcome for the individual's life, the more likely it is to affect his/her judgements of legitimacy. Accordingly, Sparks and colleagues found in their study of high security prisons (where sanctions can have relatively severe consequences, and 'news travels specially fast [so] people know about one another's outcomes as well as about procedure') that consistency of outcomes as well as procedural justice was empirically important for legitimacy. ${ }^{132}$ Similarly, in a recent study of sentencing in an English Crown Court, the authors commented that their findings supported the hypotheses of procedural justice theory; however, it was also the case that 'in the stark setting of the courtroom, the outcome of a case ... is a crucial determinant of court users' perceptions of legitimacy'. ${ }^{133}$

But in any case, the study of outcomes in individual cases is not the only issue of relevance when considering distributive justice. Take, for example, the imaginary case of Courtney, a young black student born in England, who lives in an area of London with a relatively high ethnic minority population. From his studies, he is aware of the official statistics showing that, as at March 2015, blacks in England and Wales were four times more likely than

129 Wrong, above $\mathrm{n} 12$ at 36.

130 Aristotle, above n 118 at 84 .

131 Tyler, above n 101 at 153.

132 Sparks et al, above n 68 at $88-89$.

133 J Jacobson, G Hunter and A Kirby, Inside Crown Court: Personal Experiences and Questions of Legitimacy (Bristol, Policy Press, 2015) 166. 
whites to be stopped by police: ${ }^{134}$ and he is angry about this. One day he is himself stopped by the police. Courtney regards the outcome of his case (no further action) as satisfactory and just. However, he is still angry about the frequency with which black people are stopped, and this delegitimates the police in his eyes. The distributive justice issue that concerns him is, therefore, not the outcome of his case, but the perceived over-enforcement of the law against an ethnic minority.

The perceived excessive use of police powers has often produced resentment among minority communities, sometimes leading to open confrontation between police officers and members of these communities. A well-known English example of this was the riot in Brixton, London, in 1981, sparked by a police stop-and-search operation known as Operation Swamp, which disproportionately targeted black youths. ${ }^{135} \mathrm{~A}$ more recent and more tragic set of examples is to be found in the United States, where there is evidence to show that police shootings are disproportionately focused on African Americans: for example, in 2015 there were 7.22 killings by police officers per million African Americans, compared with 2.94 per million White Americans. ${ }^{136}$ A notorious case of a black man being shot by a police officer was the death of Michael Brown in Ferguson, Missouri, in August 2014; we shall shortly explore more fully the contextual background of policing in Ferguson.

Distributive injustice can occur because of the under-enforcement, as well as the over-enforcement, of laws. According to Natapoff:

Underenforcement is a weak state response to lawbreaking as well as to victimization. It ... offers important insights into the government's relationship with vulnerable groups in the context of the criminal system. In practice, underenforcement is often linked with official discrimination, increased violence, legal failure, and the undemocratic treatment of the poor. Underenforcement can also be a form of deprivation, tracking familiar categories of race, gender, class, and political powerlessness. Conceived of as a form of public policy, underenforcement is a crucial distribution mechanism whereby the social good of lawfulness can be withheld. ${ }^{137}$

As Natapoff notes, under-enforcement can involve either a weak response to victimisation or a weak response to certain kinds of lawbreaking (in particular, the failure to pursue lawbreakers who have committed crimes against members of disadvantaged groups). Both kinds of under-enforcement have occurred in England. The first type is exemplified by the Rotherham child

\footnotetext{
134 HomeOffice, 'PolicePowersandProceduresEngland and Wales YearEnding 31 March2015' (www.gov.uk/government/publications/police-powers-and-procedures-england-and-walesyear-ending-31-march-2015/police-powers-and-procedures-england-and-wales-year-ending31-march-2015\#key-findings).

135 Scarman, above n 46.

136 The Guardian, 'The Counted: People Killed by the Police in the US': www.theguardian. com/us-news/ng-interactive/2015/jun/01/the-counted-police-killings-us-database.

137 A Natapoff, 'Underenforcement' (2006) 75 Fordham Law Review 1715 at 1717.
} 
sex abuse scandal, where, it will be recalled, the police in the area 'regard[ed] many child victims with contempt' and 'gave no priority' to this kind of crime, despite having been made aware of the scale of the problem through three independent reports. ${ }^{138}$ As a consequence, those victimised felt desperately unsupported. The second type of under-enforcement (under-enforcement of lawbreaking) became apparent in the case of Stephen Lawrence, a young black man who was murdered in the streets of south London in 1993. A prosecution of suspects initially failed to achieve conviction. Stephen Lawrence's family complained of police racism which, they claimed, had resulted in a failure by the police to take the investigatory process seriously. A commission of inquiry confirmed aspects of the complaints by the family; it found that professional incompetence and institutional racism accounted for the failure of the police to secure convictions for the murder. ${ }^{139}$

Not surprisingly, groups who experience either over-enforcement or under-enforcement of the law tend to blame the police for what they have experienced, so this often leads to a diminution of attributions of legitimacy. Accordingly, distributive fairness is an appropriate and necessary element in the police's response to the public's basic legitimation demand.

\section{Effectiveness}

In an instructive discussion, David Beetham drew attention to a distinction sometimes made by political scientists between 'legitimacy' (as a normative concept) and effectiveness (which they perceive as an instrumental concept). At one level, he argues, the distinction is valid, because the two concepts 'are not coterminous'. But matters are not as simple as this:

[T] here is a reciprocal connection between the two [concepts] ... [L] egitimacy makes a difference to the effectiveness of a system of power, through the quality of performance it secures from those subordinate to it. Equally importantly, the performance of government makes a significant difference to, and forms a necessary component of, its legitimacy ... After all, how can the enormous powers of the state be at all justified, or people obliged to obey it, unless it fulfil requirements necessary to the society and their own well being and that it fulfil them effectively? ${ }^{140}$

In the sphere of policing, societies may reasonably differ on what the specific priorities of the police should be-for example, public order, counterterrorism, property crimes, sex offences or whatever. But whichever priorities are chosen, there will be an expectation by the public that the police

138 Jay, above n 37.

139 W Macpherson, Inquiry into the Matters Arising from the Death of Stephen Lawrence: Final Report. (London, The Stationery Office, 1999).

140 Beetham, above $\mathrm{n} 4$ at 137 (emphasis added). 
should be reasonably successful in achieving results; ${ }^{141}$ if they are not, then-on Beetham's analysis-loss of legitimacy may follow.

Extensive research evidence from studies of vigilante violence supports this claim, because vigilantism usually arises in contexts where there is ineffective state policing. For example, Anderson's work in inner cities in the US found that recourse to vigilantism tends to occur in situations where, in a context of weak policing, personal concern for one's safety takes over, culminating in 'people's law', based on 'street justice'. ${ }^{142}$ The study also showed that even when the police have the capacity to intervene, they may be unwilling to respond to people's security needs: 'when called, they may not respond, which is one reason many residents feel they must be prepared to take extraordinary measures to defend themselves and their loved ones against those who are inclined to aggression'. ${ }^{143}$ Similarly, in Nigeria, a lack of police response against violent robberies contributed to the rise of the Bakassi Boys, a vigilante group that combined torture with occult forces to fight crime. ${ }^{144}$

This direct evidence from vigilantism studies of the relation between police ineffectiveness and low public perceptions of police legitimacy has been interestingly supplemented by survey research in South Africa. South Africa has a high crime rate (in 2011, 50 murders and 100 recorded rapes a day among a population of 50 million), and the purpose of the survey was to test whether, in such a context, procedural justice would feature as prominently as a predictor of legitimacy as it has done in European and North American surveys. The answer was that procedural justice remained important, but was trumped, in these conditions, by effectiveness:

We find that trust in both police procedural justice and efficacy is correlated to police legitimacy ... Yet procedural justice is a less important predictor of legitimacy than in [Anglo-American Democratic Policing] countries, while effectiveness appears to be a stronger predictor of legitimacy than studies conducted in those countries usually find ... In South Africa ... while fairness is important, effectiveness appears to be more so. ${ }^{145}$

141 Unless, of course, a completely inappropriate priority is chosen. This happened in Ferguson, Missouri, where an official Federal Government investigation found that the city government had 'consistently set maximizing revenue as the priority for Ferguson's law enforcement activity', and indeed had 'budgeted for, and achieved, significant increases in revenue from municipal code enforcement over the last several years': US Department of Justice Civil Rights Division, Investigation of the Ferguson Police Department (Washington DC, Department of Justice, 2015) 9.

142 E Anderson, Code of the Street: Decency, Violence, and the Moral Life of the Inner City (New York, Norton, 1999).

143 Ibid at 34.

144 J Harnischfeger, 'The Bakassi Boys: Fighting Crime in Nigeria' (2003) 41 Journal of Modern African Studies 23; K Meagher, 'Hijacking Civil Society: The Inside Story of the Bakassi Boys Vigilante Group of South-Eastern Nigeria' (2007) 45 Journal of Modern African Studies 89.

145 B Bradford, A Huq, J Jackson and B Roberts, 'What Price Fairness When Security Is at Stake?: Police Legitimacy in South Africa' (2014) 8 Regulation and Governance 246 at 260. 
Accordingly, far from being unconnected to legitimacy, police effectiveness can be read as a key measure of the extent to which authorities are able to solve Williams' 'first political question'. As Mulgan notes, this may have consequences well beyond criminal justice:

$[\mathrm{O}]$ rder and safety are essential not just for life to carry on but also for people to live well. The available data suggest that political stability and order, the rule of law and justice, are decisive to happiness ... It is hard to overestimate the value of strong, stable and protective and legitimate governance to human well-being. ${ }^{146}$

Mulgan's reference to 'protective and legitimate governance' raises a further important issue; namely, a possible contrast between the 'protection' offered by public police (that is, by the state) and that offered by vigilante groups or mafias. ${ }^{147}$ As Ian Loader has argued, some demands for protection are concerned simply with the prevention of immediate threat, but true security has to go beyond this:

Security inheres, rather, in the capacity of individuals and groups to feel at ease with the threats that their environment poses, such that they do not, on an everyday basis, have to think about how safe they are, or routinely concern themselves with the effectiveness of the security measures that are in place, or constantly be bothered with whether and how these may need to be bolstered. To be secure, as opposed to simply safe, is to be comfortable in, and with, one's environment and hence free from the burdens of recurring security work. ${ }^{148}$

This conceptualisation helps us to differentiate the role of state policing and the protective activities of organised gangs and similar groups. The state works within the boundaries of normative requirements in which public security is 'a right available, by reason of their membership alone, to all members of that community'. ${ }^{149}$ Organised criminal gangs, mafias, or vigilante groups do provide protection, but always partially, and sometimes in a manner that poses a threat to the safety of others, and/or without recognition of notions of justice and accountability. ${ }^{150}$ The provision of truly effective security is therefore, in principle, very much an element in the appropriate state response to citizens' basic legitimation demands. ${ }^{151}$

146 G Mulgan, Good and Bad Power (London, Penguin, 2007) 45.

147 C Tilly, 'War Making and State Making as Organized Crime' in P Evans, D Rueschemeyer and T Skocpol (eds), Bringing the State Back In (Cambridge, Cambridge University Press, 1985).

148 I Loader, 'Policing, Recognition and Belonging' (2006) 605 Annals of the American Academy of Political and Social Science 202 at 209.

149 Ibid at 207.

150 Meagher, above n 144; GD Willis, The Killing Consensus: Police, Organized Crime, and the Regulation of Life and Death in Urban Brazil (Oakland, University of California Press, 2015).

151 Effectiveness alone is however no guarantee of legitimacy, as is made clear in the quotation from Leslie Green at the beginning of this chapter: Green, above $n 1$ at 1 . 


\section{Anthony E Bottoms and Justice Tankebe}

\section{Lawfulness, or Rule-governed Power}

In Beetham's frequently-reproduced diagram setting out 'the three dimensions of legitimacy', the first of the three 'criteria of legitimacy' is described as 'conformity to rules (legal validity)'. ${ }^{152}$ However, later in the same text, in Beetham's fuller description of this criterion, matters become a little more nuanced. Here, it is said that the 'first condition' of the legitimacy of any form of social power is that the power 'should be acquired and exercised in accordance with established rules'. ${ }^{153}$ This gives a wider remit to the criterion, because the 'rules' are described as being 'either customary and conventional in form, or ... part of a legal order' ${ }^{154}$ Of course, in modern states the rules are very often formally legal, but 'even in the contemporary world the force of convention still exists'. ${ }^{155}$

Both formal legality and informal conventions are therefore relevant to this component of legitimation and legitimacy. Police officers often and rightly appeal to formal legal provisions as the basis for their actions, especially when they make coercive and potentially controversial interventions in people's lives-such as stop and search, arrest, interrogation, communications intercepts, and (in exceptional circumstances) the shooting of a suspect. But, as Beetham points out, if people in power appeal to the law as the justificatory legitimation for their coercive actions, it follows that they must also 'respect [the law] themselves for their legitimacy to be sustained'.156 More generally (and now embracing conventions as well as formal law), it follows from the nature of social rules that in any rule-governed social order the existence and acquisition of power cannot be separated from the normative expectations ... by reference to which its possession is justified' ${ }^{157}$

This set of ideas in turn explains the importance of the concept of the 'rule of law', described by Beetham as (among other things) embracing the view that 'the powerful and their agents, whatever influence they may exercise over the formulation of the law, are themselves subject to it and have to conform to recognised procedures if they wish to change it'. ${ }^{158}$ The rule of law has been described by the American legal theorist Brian Tamanaha as 'the dominant legitimating slogan of law at the close of the twentieth century'. ${ }^{159}$ At its heart are principles of due process and equality, and an expectation that those who enforce the law, including the police, must do so

\footnotetext{
152 Beetham, above $\mathrm{n} 4$ at 20 .

153 Ibid at 64 .

154 Ibid at 65 (emphasis added).

155 Ibid at 66.

156 Ibid at 68

157 Ibid at 65 .

158 Ibid at 68

159 Tamanaha, above $\mathrm{n} 95$ at 98 .
} 
in a manner that is 'unbiased, free of passion, prejudice, and arbitrariness, loyal to the law alone'. ${ }^{160}$ When these principles are followed, there is of course an overlap between lawfulness, procedural justice and distributive justice.

Unfortunately, however, the police do not always behave in accordance with formal legal requirements, nor with informal conventions as to how law enforcement officials should behave. ${ }^{161}$ Such actions can cause (and historically have caused) deep disquiet and a withdrawal of confidence in the police in certain communities, especially underprivileged and/or minority communities, as is illustrated by the investigation by the US Department of Justice into the police department in Ferguson, Missouri, after the shooting of Michael Brown (an incident we have already alluded to above). The Table of Contents at the beginning of the report of this investigation is itself a damning indictment of the Ferguson Police Department (FPD), as the following extracts show:

- FPD Engages in a Pattern of Unconstitutional Stops and Arrests in Violation of the Fourth Amendment [of the US Constitution];

- FPD Engages in a Pattern of Excessive Force in Violation of the Fourth Amendment [of the US Constitution];

- Ferguson Law Enforcement Practices Disproportionately Harm Ferguson's African-American Residents and Are Driven in Part by Racial Bias;

- Ferguson's Law Enforcement Practices Erode Community Trust, Especially Among Ferguson's African-American Residents. ${ }^{162}$

The report also shows that these key points are interconnected:

Our investigation showed that the disconnect and distrust between much of Ferguson's African-American community and FPD is caused largely by years of the unlawful and unfair law enforcement practices by Ferguson's police department ... We heard from African-American residents who told us of Ferguson's 'long history of targeting blacks for harassment and degrading treatment' and who described the steps they take to avoid this-from taking routes to work that skirt Ferguson to moving out of state. An African-American minister of a church in a

160 B Tamanaha, On the Rule of Law: History, Politics, Theory (Cambridge, Cambridge University Press, 2004) 123.

161 For a remarkable example of a breach of informal conventions, see the evidence of undercover male police officers in England entering into long-term sexual relationships with female political activists, including in some cases fathering children. This evidence was first brought to light by investigative journalists (R Evans and P Lewis, Undercover: The True Story of Britain's Secret Police (London, Guardian Books, 2013)), and is now among the matters being considered in a broader judicial inquiry into undercover policing set up in 2015, chaired by Sir Christopher Pitchford.

162 US Department of Justice Civil Rights Division, above n 141, at i (capitalisation in original). 


\section{Anthony E Bottoms and Justice Tankebe}

nearby community told us that he doesn't allow his two sons to drive through Ferguson out of 'fear that they will be targeted for arrest'. ${ }^{163}$

It is worth emphasising that these practices had developed within a country that is rightly proud of its liberal-democratic traditions, and that has enshrined within its constitution a strong Bill of Rights. The stark contrast between the constitutional rhetoric and the actual practices of policing in Ferguson emphasises the need for strong accountability structures for policing within liberal-democratic states.

Of course, police unlawfulness is not always as systematic as it apparently was in Ferguson. For example, on specific occasions a group of officers might be tempted to engage in what has come to be known, rather unfortunately, as 'noble cause corruption'-that is, the use by the police of 'illicit means for organisationally and socially approved ends' ${ }^{164}$ Thus, in a high profile case, securing conviction of an 'obviously' guilty person might seem to investigating officers to be an act that is clearly in line with the police's mission, and one that will be approved of by the general population. So if the evidence does not seem quite sufficient to achieve a conviction, there might be a temptation to improve it-by, for example, planting or falsifying some evidence, or engaging in unlawful practices of interrogation in order to secure a confession. ${ }^{165}$ This is a form of 'cognitive ethical failure', as previously described; ${ }^{166}$ but while it might appear to have social benefits, it can also lead to delegitimation if and when the illegality is discoveredespecially if the suspected person is convicted, but then found to be innocent, as has happened in some high profile cases.

\section{E. Realism and the 'Basic Legitimation Demand'}

We have suggested that the four issues we have identified (procedural justice, distributive justice, effectiveness and lawfulness) are matters that will very often, and quite naturally, be raised within empirically realist discussions of 'what, here and now, makes sense as a legitimation of power'. ${ }^{167}$ We do not, of course, claim that all four of them will be raised within every legitimation discussion, because real-world debates do not work like that.

163 Ibid at 79. The situation was also, of course, exacerbated by the demands of the city authorities in Ferguson for the police to generate additional revenue for the city's budget by an increased use of ticketing for municipal code violations: see above $n 141$.

164 Punch, above n 35 at 305.

165 Sometimes illegalities can also be perpetrated for less 'noble' reasons. For example, in a highly publicised case, police officers in Brooklyn, New York, were convicted for planting narcotics on people when they 'needed a productivity boost': New York Times (14 October 2011).

166 Price, above n 98.

167 Williams, above $\mathrm{n} 5$ at 11 
Rather, as we have previously suggested, such debates occur especially when there are legitimacy deficits, and they are often heavily influenced by the history and culture of the local situation. Thus, there is much that is contingent about legitimacy debates. Bearing that in mind, our claims are first, that the four issues we have identified are, empirically speaking, not infrequently raised in legitimation discussions; and second, that there are good normative reasons, relating to the concept of justified political authority, why they are regularly raised.

The four issues must, however, always be seen as potentially operating in interaction with one another; and they will not always work in harmony. In particular, there can be tensions between effectiveness and each of the other three matters. The potential tension with lawfulness has been discussed above, but effectiveness can sometimes also seem to conflict with distributive justice (as where a type of crime appears to be committed particularly frequently by a given ethnic group) and with procedural justice (as where, in the wake of terrorist incidents, officers want to concentrate on preventive actions, and so wish to pay less attention to treating everyone with humanity). In dealing with such tensions and conflicts, we suggest that Amartya Sen's 'impartial spectator test' will be a valuable resource, and will help police services to focus on longer-term social consequences, as well as on the immediate situation.

There is also a further point of some theoretical importance that arises from the analysis in this section. Diarmaid Harkin has insightfully pointed out that while there is a general consensus in the academic literature on policing that 'legitimacy is undermined by corruption, brutality and dishonesty', nevertheless, when examples of such behaviour come to light, they 'are rarely catastrophic for the police, but contained in their impact'. ${ }^{168}$ As a possible explanation of this phenomenon, Harkin draws attention to the potential relevance of John Jost's psychological 'system justification theory', according to which there is 'a general ideological motive to justify the existing social order'; ${ }^{169}$ but there are at least two other possible, and more sociological, explanations. One would rely on Margaret Gilbert's concept of a 'joint commitment', ${ }^{170}$ and the argument would be that many aspects of such a commitment can survive even some major shocks. The second possibility would draw attention to the fact that legitimation and legitimacy are always political issues, and have to be viewed within the context of the particular political system in which they occur.

168 Harkin, above n 109 at 601.

169 JT Jost, MR Banaji and B Nosek, 'A Decade of System Justification Theory: Accumulated Evidence of Conscious and Unconscious Bolstering of the Status Quo' (2004) 25 Political Psychology 881.

170 Gilbert, above n 55. 
This second possibility is well illustrated by some events in the Republic of Ireland, as described by Vicky Conway (not cited by Harkin). ${ }^{171}$ In County Donegal, a disturbing series of allegations about the police emerged from 1996 onwards; these were eventually considered by a tribunal presided over by a High Court judge (Justice Morris), which sat for six years from 2002, and issued eight reports. The findings of the tribunal were 'exceptionally critical' of the police, documenting 'corruption, abuse of power and negligence from management', as well as 'a disregard for procedure at every turn and a belief that this could be done with impunity'. ${ }^{172}$ Yet despite all this, a national survey of public confidence in the police showed only a small change from 2002 to 2008 (86 per cent satisfied or very satisfied in 2002; 81 per cent in 2008); and among the 26 counties in the Irish Republic, respondents in Donegal recorded the second highest level of confidence. ${ }^{173}$ Conway suggests some reasons for these striking findings, based on Ireland's complex post-colonial history, and the ideological importance of the Irish gardai (police) within that history. The details of her discussion need not concern us here, but we do need to note the importance of the historical dimension in this example, because-as previously noted-how people judge the police in a particular situation very often depends upon prior experiences and understandings. ${ }^{174}$

Yet given the dialogic nature of legitimacy, and the existence of multiple dialogues (see above), the lack of impact on the general public of events such as those in Donegal might not be the only relevant issue. For example, studies in political science have shown that when a political leader loses the confidence (legitimacy) previously placed in him or her by elites close to the sources of power, this can be fatal for his/her effective continuance in office. ${ }^{175}$ Thus, in the policing context, not only public perceptions, but also the state's more formal mechanisms of accountability in relation to the policing function are a vital element in the total set of dialogues about legitimacy. ${ }^{176}$ In other words—and unsurprisingly—a realist political analysis of police legitimacy ultimately requires attention to many aspects of state functioning.

The upshot of the discussion in this section is therefore that procedural justice, distributive justice, effectiveness and lawfulness can be empirically

171 V Conway, Policing Twentieth Century Ireland: A History of An Garda Siochana (London, Routledge, 2014) ch 8.

172 Ibid at 188 .

173 Ibid at 192.

174 Harkin, above n 109.

175 R Barker, Legitimating Identities: The Self-Representation of Rulers and Subjects (Cambridge, Cambridge University Press, 2001); J Rothschild, 'Observations on Legitimacy in Contemporary Europe’ (1977) 92 Political Science Quarterly 487.

176 Conway is highly critical of police accountability mechanisms in the Republic of Ireland, where, she claims, the national government has traditionally held a 'controlling influence over policing': Conway, above n 171 at 217. 
identified as important potential contributors to discussions about police legitimation and legitimacy. But these matters can sometimes be in tension with one another; and, given the historical and contextual contingency of legitimacy discussions, in a particular context one or more of them might not have the impact that one would normally anticipate.

As a final comment, the preceding discussion has assumed that the legitimation discussion is taking place within Williams' 'realist' framework, which means that the conception of legitimacy adopted is ultimately empirical. We have argued above that such a framework, although immensely analytically valuable, needs buttressing by some bedrock normative commitments. This is not the place for an extended discussion of what those commitments should be, but in brief we would argue that they should be based on the concept of human rights, and they would therefore be very similar to those contained in the US Bill of Rights or the European Convention on Human Rights. Provisions of this sort would be sufficient to deal with the example that we have used throughout this chapter of the proposal for forced deportation of an ethnic minority in 'Dystopia'; clearly, such a proposal would violate such a Bill or Convention.

\section{CONCLUSION}

The analysis in this chapter has, we hope, demonstrated that the legitimacy of the public police is, in contemporary states, an issue of central importance with regard to what Bernard Williams described as 'the first political question' for any state, namely the establishment and maintenance of 'order, protection, safety, trust, and the conditions of co-operation'. ${ }^{177}$ Our analysis of this issue has drawn upon prior criminological work on police legitimacy, but it has also considered two concepts from political philosophy not previously discussed within the criminological literature on legitimacy, namely Williams' 'Basic Legitimation Demand' and Amartya Sen's 'impartial spectator'.

Our analysis has been primarily theoretical, but by drawing upon the empirical research literatures on both policing in general, and on the legitimacy of the police in particular, it has sought to remain aware of the day-to-day realities of policing. Indeed, our hope is that some of the central topics discussed here could be of practical assistance to police leaders as they seek to deliver just and legitimate policing. These topics include, first and foremost, Williams' suggestion that there is a need for those, like the police, who are invested with state powers to be able to offer a legitimation to every subject as to why the use of those powers is normatively justified.

177 Williams, above n 5 at 3. 
Bearing in mind Tom Tyler's concept of the 'teachable moment', ${ }^{178}$ we can reasonably add that in principle this requirement needs to be met on every occasion that police powers are used. These are stringent requirements, but police officers need to remember that, in the last resort, they are-as Williams crudely but correctly put it-simply 'one lot of people' who have been given power over 'another lot of people'; and, since 'power itself does not justify', the justification of police power is in principle continually necessary. ${ }^{179}$ Of course, the sociological reality is-as the events dealt with by the Morris Tribunal in Ireland particularly demonstrate ${ }^{180}$ — that sometimes the police can rely on their accumulated public goodwill to retain legitimacy even when they have behaved in unjustifiable ways. But legitimacy is a dialogic process involving many layers, many players, and an unfolding series of events, and it would be an unwise police leader who believes that his or her police service can sustain legitimacy indefinitely in such circumstances. Unwise police leaders do, sadly, exist, but their normative failures are more often, in Terry Price's language, cognitive rather than volitional; ${ }^{181}$ and we have suggested that if they were to use Amartya Sen's 'impartial spectator test' ${ }^{182}$ the number of such failures would be reduced.

Police officers at all levels are reasonably entitled to ask scholars of policing whether their research and theorisation can offer any practical guidance as to how police legitimacy can be developed and sustained. As we have shown, legitimacy dialogues are always contingent on specific features of the place and time in which they occur, and are influenced by the history and culture of that place and time; and this means that the specifics of legitimation and legitimacy can be very variable. We have however suggested the enduring importance of procedural justice, distributive justice, effectiveness and lawfulness as guides to the delivery of legitimate policing. Perhaps the best way to describe their potential importance as a practical guide is to say, first, that firm evidence can be cited that a failure to deliver any one of these four matters has on some occasions led to a legitimacy deficit for a public police service; but second, there are no reports of a police service that has delivered all four of them, and has lost its legitimacy.

178 Tyler, above n 107 at 257.

179 Williams, above $\mathrm{n} 5$ at 5.

180 Conway, above n 171.

181 Price, above n 98; Hales et al, above n 99.

182 Sen, above n 6. 